\title{
Deep chlorophyll maximum and upper ocean structure interactions: Case of the Guinea Thermal Dome
}

\author{
by Olaf Duteil, ${ }^{1,2,3,4}$ Alban Lazar, ${ }^{5,6}$ Yves Dandonneau, $^{7}$ Ilana Wainer ${ }^{1}$ and \\ Christophe Menkes ${ }^{7,8}$
}

\begin{abstract}
Deep Chlorophyll Maximum (DCM) modifies the upper ocean heat capture distribution and thus impacts water column temperature and stratification, as well as biogeochemical processes. This energetical role of the DCM is assessed using a $1 \mathrm{~m}$-resolution 1D physical-biogeochemical model of the upper ocean, using climatological forcing conditions of the Guinea Dome (GD). This zone has been chosen among others because a strong and shallow DCM is present all year round. The results show that the DCM warms the seasonal thermocline by $+2^{\circ} \mathrm{C}$ in September/October and causes an increase of heat transfer from below into the mixed layer (ML) by vertical diffusion and entrainment, leading to a ML warming of about $0.3^{\circ} \mathrm{C}$ in October. In the permanent thermocline, temperature decreases by up to $2^{\circ} \mathrm{C}$. The result is a stratification increase of the water column by $0.3^{\circ} \mathrm{C} \mathrm{m}^{-1}$ which improves the thermocline realism when compared with observations. At the same time, the heating associated with the DCM is responsible for an increase of nitrate $(+300 \%, 0.024 \mu \mathrm{M})$, chlorophyll $\left(+50 \%, 0.02 \mu \mathrm{g} \mathrm{1^{-1 }}\right)$ and primary production ( $+45 \%: 10 \mathrm{mg} \mathrm{C} \mathrm{m}^{-2}$ day $^{-1}$ ) in the ML during the entrainment period of October. The considered concentrations are small but this mechanism could be potentially important to give a better explanation of why there is a significant amount of nitrate in the ML. The mechanisms associated with the DCM presence, no matter which temperature or biogeochemical tracers are concerned, are likely to occur in a wide range of tropical or subpolar regions; in these zones a pronounced DCM is present at least episodically at shallow or moderate depths. These results can be generalized to other thermal dome regions where relatively similar physical and biogeochemical structures are encountered. After testing different vertical resolutions ( $10 \mathrm{~m}, 5 \mathrm{~m}, 2.5 \mathrm{~m}, 1 \mathrm{~m}$ and $0.5 \mathrm{~m}$ ), we show that using at least a $1 \mathrm{~m}$ vertical resolution model is mandatory to assess the energetical importance of the DCM.
\end{abstract}

1. Univ. de Sao Paulo-Instituto Oceanografico, Praca do Oceanografico, 191. Cidade Universitaria. Sao Paulo, Brasil.

2. LOCEAN-IPSL (CNRS, IRD, UPMC)/Univ. Paris VI, 4 place Jussieu, 75252 Paris cedex 05, France.

3. Current address: Leibniz-Institut für Meereswissenschaften, IFM-GEOMAR, Düsternbrooker Weg 20, 24105 Kiel, Germany

4. Corresponding author.email: oduteil@ifm-geomar.de

5. UPMC, LOCEAN-IPSL (CNRS, IRD, UPMC)/Univ. Paris VI, 4 place Jussieu, 75252 Paris cedex 05, France.

6. IRD, LPAOSF, ESP-Université Cheikh Anta Diop, BP 5085, Dakar-Fann, Senegal.

7. IRD, LOCEAN-IPSL (CNRS, IRD, UPMC)/Univ. Paris VI, 4 place Jussieu, 75252 Paris cedex 05, France.

8. IRD Noumea/101 promenade Laroque, BP A5, 98848 Noumea cedex, New Caledonia. 


\section{Introduction}

Global warming is expected to increase the average upper ocean temperature, leading to enhanced stratification which could reduce nutrient fluxes to the photic layer and thus primary production (Bopp et al., 2001). To realistically assess such upper ocean temperature and ecosystem modifications, one needs to consider the processes influencing the pycnocline/nutricline depths as accurately as possible. A complex feedback exists as production itself controls light absorption by changing water turbidity: Jerlov (1976) classified the ocean waters in six types depending on their concentration of organic material. Early parameterizations (Denman, 1973; Paulson and Simpson, 1977) of the irradiance exponential profile were based on the experimental measurement of light absorption coefficients at one or more wavelengths for a specific Jerlov water type. To give a better representation of the irradiance field, light absorption coefficients must explicitly take into account the biological material concentration, which can be approximated by chlorophyll concentration, as proposed by Morel (1988). Light absorption by chlorophyll leads to the modification of the penetrating heating flux in the water column, which is derived from the light penetrating gradient, as shown by Morel and Antoine (1994).

Previous studies of stand alone ocean models have shown that implementation of this light penetration formulation results in a marked impact of the chlorophyll on the structure of the surface layers which can lead to changes in the mean state, either in seasonal or intra-seasonal variability (Sathyendranath, 1991; Nakamoto et al., 2001; Murtugudde et al., 2002; Marzeion et al., 2005; Manizza et al., 2005; Oschlies, 2004; Lengaigne et al., 2006; Wetzel et al., 2007). However, no clear or coherent sea surface temperature (SST) changes emerge from any of these studies (see Lengaigne et al., 2006, for a discussion). Indeed, how sea surface temperatures change with such biooptical feedback is not obvious.

In a 1-D view, where chlorophyll concentration increases in the ML, radiant heat is absorbed in a shallower layer which by itself would result in a higher temperature in the upper ocean and lower at the subsurface (e.g.: Nakamoto et al., 2001). Lower temperatures at depth can result in enhanced advection of cooler water. The resulting sea surface can actually be cooled by optical feedbacks (Manizza et al., 2005).

In a 3-D framework, the picture gets more complicated due to ocean lateral processes, which can reduce or enhance 1-D mechanisms. In coupled ocean-atmosphere frameworks, the retroactions are even more complicated and sometimes cannot be sorted out (e.g.: Lengaigne $e t$ al., 2006). An additional difficulty that arises in all previous studies dealing with such retroactions is that a reference simulation must be chosen in order to be able to isolate the effect of heating by chlorophyll. Should this reference be an abiotic ocean (Marzeion et al., 2005)? How should we decide which average chlorophyll it should contain?

The choice of reference is crucial: the amplitude and even the sign of resulting temperature anomalies are linked to that choice (see Lengaigne et al., 2006 or Wetzel et al., 2007 for discussion). Finally, most of the studies differ by the way they actually represent the light-chlorophyll feedback, which makes their comparisons even more difficult. For 
Table 1. Examples of shallow DCM description in literature (zDCM is the DCM depth (m), cSurf is the surface chlorophyll concentration and cDCM, the maximal chlorophyll concentration $\left(\mu \mathrm{g}^{-1}\right)$

\begin{tabular}{|c|c|}
\hline A utbore & Region \\
\hline
\end{tabular}

1. Voituriez and

Dandonneau, 1974

2. Faugeras et al., 2003

3. Richardson et al., 2002

4. Corredor et al., 2004

5. Vaillancourt et al., 2003

6. Cullen et Eppley, 1981

7. Choi et al., 1995

8. Sharples et al., 2001

9. Di Tullio et al., 2003
Guinea Dome

Mediterranean sea

Benguella

upwelling system

Caribbean sea

Tropical Pacific ocean

Californian upwelling system

Yellow sea

English channel

Subtropical Pacific ocean
August 1973

July 1997

Summer

1993-1994

August 2003

November 2000

March 1979

October 1992

August 1999

February 1996
30

0.2

1.25

40

0.05

0.3

1

25

55

0.05

0.5

55

0.1

0.45

20

0.3

1.1

30

0.2

1.3

30

0.1-0.3

26

50

$0.1-0.2$

$0.3-0.4$

instance; the chlorophyll concentration used in the optical formulation can be derived from satellite measurements (Sathyendranath et al., 1991, Nakamoto et al., 2001; Murtugudde et al., 2002) or obtained by coupling a biogeochemical model (Manizza et al., 2005; Oschlies, 2004, Lengaigne et al., 2006). In the first case, the structure of the vertical profile of chlorophyll is not considered, as satellite sensors detect an integral of the chlorophyll concentration in the upper euphotic zone (Sathyendranath et al., 2001). Today, this strategy is used in several modern OGCM and climate models, such as the CCSM 3 (Collins et al., 2006). In the latter case, the vertical distribution of chlorophyll is represented. A feature that can bias the previous results is the low vertical resolution used (typically $10 \mathrm{~m}$ or more in the upper thermocline), which is unlikely to give a good representation of the common chlorophyll feature known as deep chlorophyll maximum (DCM).

Most of the previous studies have usually focused on the upwelling regions where chlorophyll can be high. Thus intense light retroaction can be expected. Yet, in most regions of the globe, the most common feature of chlorophyll vertical profile is the DCM which is generally located just below the pycnocline (Herbland and Voituriez, 1979; Agusti and Duarte, 1999). It is a ubiquitous pattern in world oceans, as illustrated in Table 1. A shallow DCM has been reported in regions presenting thermocline crests, like the Guinea Dome (GD) (Voituriez and Dandonneau, 1974; Breves et al., 2003), but also in major upwelling systems (Cullen and Eppley, 1981; Richardson et al., 2002), under weak upwelling conditions, and during spring and summer in subtropical temperate regions when the mixed layer (ML) is shallow (Faugeras et al., 2003; Choi et al., 1995). Continental seas can be the location of a shallow and particularly strong DCM, such as the English Channel (Sharples et al., 


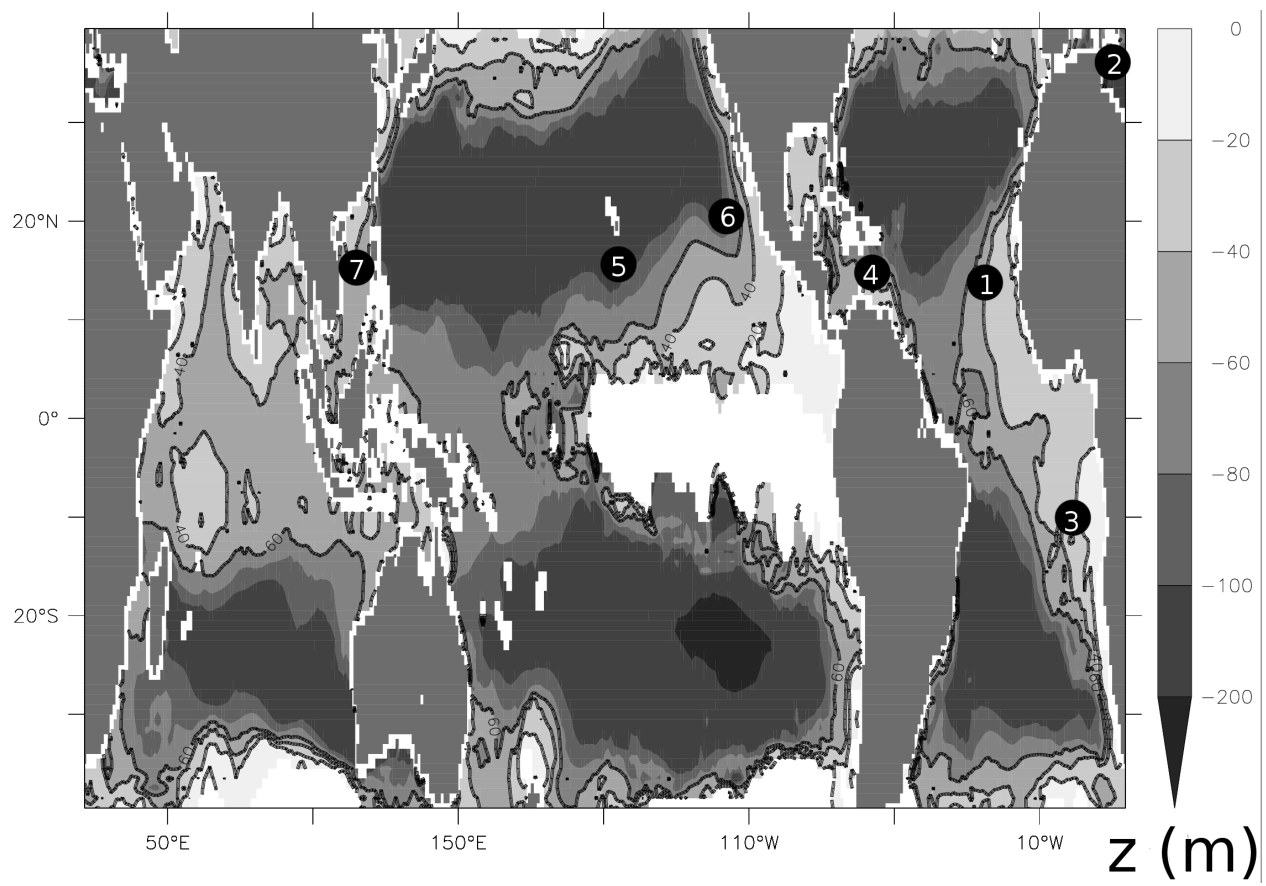

Figure 1. World map presenting regions where a shallow DCM has been described (black numbered points - see Table 1). Gray: nitracline depth (m) computing from World Ocean Atlas (2001) data (threshold $1 \mu \mathrm{M}$ ). Areas in white are zones where nitrate concentration is always greater than $1 \mu \mathrm{M}$ : presence of a DCM is unlikely in these regions.

2001). The regions listed above are located where climatological nitracline is shallow (Fig. 1). A shallow DCM can also occur episodically in regions presenting a much deeper climatological nitracline, when the latter is raised by mesoscale processes (Vaillancourt et al., 2003; Corredor et al., 2004; Menkes et al., 2002).

The scientific community has overlooked the DCM impact on heat fluxes until now. Morel and Antoine (1994) stated that a nonuniform pigment profile might modify local heating in some regions depending on its intensity and depth. More recent studies show that the DCM can have an impact on optical properties of ocean surface waters (Ballestero, 1999; Stramska and Stramski, 2005). To our knowledge, the sole study of DCM impact on the heat fluxes has been conducted by Lewis et al. (1983). Using an idealized Gaussian chlorophyll distribution, they showed that temperature tends to increase at the DCM level. Following Lewis et al. (1990) this temperature increase at depth may theoretically lead to the formation of a convective cell, which reorganizes stratification.

In this study, we analyze the mechanisms by which the DCM has an impact on the temperature, nitrate and chlorophyll vertical structure in a shallow thermocline zone by using a high vertical resolution coupled dynamical-biogeochemical-bioptical model, 
where biooptical feedback takes place. We chose the Guinea Dome (GD) to test its potential effect.

\section{Regional context and study methodology}

\section{a. Guinea Dome region}

Thermal domes are eastern extensions of equatorial current systems. They are in evidence from observational data and are characterized by upward displacements of isotherms in the thermocline layer down to a 300-m depth (Voituriez, 1981). The GD and the Angola dome are located in the Atlantic Ocean (Siedler et al., 1992; Yamagata and Lizuka, 1995). The Costa Rica dome is present in the Pacific Ocean (Fiedler, 2002). An Indian dome has also been reported (Masamuto and Meyers, 1998).

The GD is part of the thermocline zonal ridge and appears as a "mountain" between the North Equatorial Current (NEC) and the North Equatorial Counter Current (NECC). It presents a cyclonic circulation. Its seasonal variability is important, as the upward displacement of isotherms is more visible in summer/autumn. It weakens in winter (Siedler et al., 1992; Yamagata and Lizuka, 1995) and could even disappear (Voituriez, 1981; Lazaro, et al., 2005).

In situ observations and model data have shown that its location is relatively steady, at about $12^{\circ} \mathrm{N} / 22-23^{\circ} \mathrm{W}$ (Siedler et al., 1992; Yamagata and Lizuka, 1995). Following Siedler et al. (1992) the GD is generated primarily by large-scale wind field, whereas Yamagata and Lizuka (1995) found that the GD is cooled during the boreal summer and autumn by the divergence of the heat transport generated by the local Ekman pumping. This positive pumping is associated with the West African monsoon and the large-scale northeast trade winds which converge into the Inter Tropical Convergence Zone (ITCZ). Using satellite data, Lazaro et al. (2005) found a greater seasonal variability with a displacement from $9.5^{\circ} \mathrm{N} / 22^{\circ} \mathrm{W}$ in March to $11^{\circ} \mathrm{N} / 29^{\circ} \mathrm{W}$ in October. This shift is associated with the NECC migration, and then the ITCZ location, suggesting the importance of the Ekman pumping in the GD generation.

We determined the GD position using a half degree longitude and latitude resolution of the ORCA model, a fully prognostic OGCM based on primitive equations (Madec et al., 1999); the forcing conditions of the $1 \mathrm{D}$ model are located at $12^{\circ} \mathrm{N} / 25^{\circ} \mathrm{W}$. It is the place where the top of the thermocline is shallowest at annual mean in the eastern tropical Atlantic in the ORCA05 model; the ratio of vertical to total heat advection is maximum. This location is in agreement with the GD position in literature.

\section{b. 1D Water column model}

The 1D model we used is a simplified version of the 3D ORCA05 model. In order to accurately reproduce the upper ocean structure, its vertical resolution is $1 \mathrm{~m}$ in the upper $120 \mathrm{~m}$. Between 100 and $120 \mathrm{~m}$ a sponge layer permits a progressive transition between the 
free modeled variables at $100 \mathrm{~m}$ and climatological temperature and salinity ORCA05 fields at $120 \mathrm{~m}$. To complete the dynamics of the 1-D diffusion model (based, on TKE, Gaspar et al., 1990) we use a vertical velocity field given by OPA ORCA05 climatologies to introduce a vertical advection term. Forced horizontal advection and diffusion are given by ORCA05 climatology and have also been added to prevent the system from drifting (LBF or Lateral Boundary Fluxes in the equations below):

$L B F=-u_{\text {ORCA05 }} \frac{\partial T_{\text {ORCA05 }}}{\partial x}-v_{\text {ORCA05 }} \frac{\partial T_{\text {ORCA05 }}}{\partial y}$

$$
+\frac{\partial}{\partial x}\left(K_{H} \frac{\partial T_{\text {ORCA05 }}}{\partial x}\right)+\frac{\partial}{\partial y}\left(K_{H} \frac{\partial T_{\text {ORCA05 }}}{\partial y}\right),
$$

where $K_{H}$ is the horizontal diffusion coefficient.

The temperature evolution at any depth is given by:

$$
\frac{\partial T}{\partial t}=-w_{O R C A 05} \frac{\partial T}{\partial z}+\frac{\partial}{\partial z}\left(K_{z} \frac{\partial T}{\partial z}\right)+Q_{S} \frac{\partial f(z)}{\partial z}+L B F
$$

with the following surface boundary condition:

$$
\left(K_{z} \frac{\partial T}{\partial z}\right)_{z=0}=\frac{Q^{*}}{\rho 0 C_{p}}
$$

where $T$ is the potential temperature, $K_{\rho}$ the vertical diffusion coefficient for tracers, $u, v$, $w$ the zonal, meridionnal and vertical current velocity components, $\rho_{0} C_{p}$ the volumic specific heat of seawater, $Q^{*}$ the non penetrative part of the surface heat flux (sensible, latent and longwave heat fluxes), $Q s$ the penetrative solar heat flux and $f(z)$ the fraction of solar heat flux heating that reaches the depth $z$ (see Optical Model).

A mixed layer budget method (Menkes et al., 2006; Vialard et al., 2001) is used to compute the vertically averaged temperature tendency trends within the time-varying mixed layer depth. The base of the mixed layer $h$, is defined as the depth where the temperature reaches the $10-\mathrm{m}$ depth temperature minus $0.2^{\circ} \mathrm{C}$ following De Boyer Montegut et al. (2004) as discussed in Section 3a. The mixed layer temperature $\mathrm{Tml}$ is an excellent proxy for the SST. The equation for $\mathrm{Tm} l$ can be written as:

$$
\begin{gathered}
\partial_{t} T m l=\underbrace{\frac{Q^{*}+Q_{s}[1-f(-h)]}{\rho_{0} \cdot C_{p} \cdot h}+\underbrace{\frac{1}{h} \int_{-h}^{0}(L B F) d z}_{B}}_{A} \\
\underbrace{-\left(\partial_{t} h+w_{\text {ORCA05 }}(-h)\right) \cdot\left(\frac{T m l-T(-h)}{h}\right)+\frac{\left(K_{\rho} \partial_{z} T\right)(-h)}{h}}_{C}
\end{gathered}
$$

where LBF is from Eq. (1). 
Eq. (4) can be decomposed into three terms: an atmospheric forcing representing the heat flux stored in the mixed layer (term A); a vertically averaged horizontal transport and diffusion trend from lateral boundaries (term B) and the term $\mathrm{C}$ (referred to as "subsurface") represents the exchanges with the deeper ocean. It includes the entrainment through the base of the mixed layer, the turbulent mixing, and vertical advection at the mixed layer base.

Vertical eddy diffusivity and viscosity coefficients are computed using a 1.5 order turbulent closure scheme which explicitly formulates the mixed layer and produces a minimum of diffusion in the thermocline (Gaspar et al., 1990). Diffusion coefficient background has been set to $1 e-6 \mathrm{~m}^{2} \mathrm{~s}^{-1}$. Air-sea fluxes are computed using bulk formulation based on the ECMWF ERA40 reanalysis climatology.

\section{c. Biogeochemical model}

The PISCES bio-geochemical model (Aumont and Bopp, 2006) is used. It contains 24 variables, with two sizes of phytoplankton (diatoms and nanophytoplankton) and zooplankton (microzooplankton and mesozooplankton), as well as nutrients and limitation by iron and silicate. It also contains labile and dissolved organic matter, but no bacteria. PISCES is coupled online with the 1D model, with the same vertical and time step resolution. The model has been initialized using World Ocean Atlas data. We verified that the tracer dynamics are mainly vertical. Unlike the physical model, we did not implement climatological horizontal advection and diffusion of theses tracers.

Primary production is limited by nutrients in the GD; thus a key factor in the model behavior is the nitrate remineralization rate, as it directly impacts the available nutrient concentration below the euphotic zone and then the fueling of primary production. As nitrate concentration is climatological at depth, if the remineralization rate is too high in the upper ocean, nitrate concentration will present a maximum below the DCM. Inversely, if this rate is weak, nitrate concentration will present a minimum below the DCM. To avoid these possible biases, we progressively restored the nitrate concentration below the euphotic zone at each time step (considered as the upper $100 \mathrm{~m}$ ), using a statistical relationship between temperature and nitrate (Voituriez and Herbland, 1983). Nitrate concentration is expressed in $\mu \mathrm{M}$.

$$
\text { Nitrate }=-1.88 T+45.49
$$

The remineralization rate is set to $0.05 \mathrm{day}^{-1}$, as defined by Aumont and Bopp (2006). This parameter has been adjusted over the Atlantic Ocean by comparison with time series station data. The same value has been used by Oschlies and Garçon (1999).

\section{d. Optical model}

The optical model, which computes irradiance $E(z)$ at each vertical level, is the Red Green Blue (RGB) model, used by Lengaigne et al. (2006). The spectrum of incoming radiation is divided into four wavelengths: infrared (greater than $700 \mathrm{~nm}$ ), red $(600-$ 
$700 \mathrm{~nm})$, green $(500-600 \mathrm{~nm})$ and blue $(400-500 \mathrm{~nm})$. The energy at the surface depends on the solar incoming radiation $E(0)$

$$
E_{R}(0)=E_{G}(0)=E_{B}(0)=0.43 E(0) ; E_{I R}=0.57 E(0)
$$

For a given wavelength, irradiance $E \lambda$ at level ( $z)$ depends on $E \lambda$ at level $(z-1)$ multiplied by an absorption coefficient $K \lambda$. Total irradiance $E$ is the sum of $E \lambda$ for the whole spectrum. Each band has a specific absorption coefficient depending on chlorophyll concentration [Chl], (Morel and Antoine, 1994; Morel, 1988), used as a proxy for light absorbing photosynthetic pigments.

$$
E(z)=\sum E_{\lambda}(z-1) e^{-K(\lambda) \Delta z}
$$

with

$$
K(\lambda)=K w(\lambda)+K c(\lambda)[C h l]^{e(\lambda)}
$$

where $K w$ is the absorption coefficient of pure seawater at a given wavelength, $K c$ is an empirical function and $e(\lambda)$ a coefficient. In the RGB model, these coefficients have been deduced from the high resolution spectrum given by Morel (1988); the RGB and the Morel model present very close results (Lengaigne et al., 2006). The optical model is coupled with the physical model to compute the heating rate $Q(z)$ :

$$
Q(z)=\frac{1}{\rho_{0} C_{p}} \frac{\partial E}{\partial z}
$$

where $C p$ is the heat capacity coefficient.

The same optical model is also used in the PISCES model to compute irradiance for phytoplankton growth.

\section{e. Modeling experiments}

We conducted two experiments. In the first one, fully coupled (CHLDEEP), the chlorophyll concentration used by the optical model is that which is computed by the biogeochemical model PISCES for all vertical levels. In the second one, CHLSURF for constant chlorophyll, we did not consider any retroaction of phytoplankton vertical profile on light absorption: although chlorophyll concentration is computed by the PISCES model, the chlorophyll concentration used by the optical model to compute irradiance at a given time has been set to a constant value throughout the entire water column. This value is the surface value of the CHLDEEP experiment. The specific effect of the chlorophyll vertical profile on thermal stratification, nutrient supplies and chlorophyll can be assessed by comparing CHLDEEP and CHLSURF outputs, as the surface chlorophyll concentration is the same in both experiments.

The spin up time of the model is 10 years: after which, no noticeable drift in temperature, salinity or biological tracers remains in CHLDEEP nor in CHLSURF. 

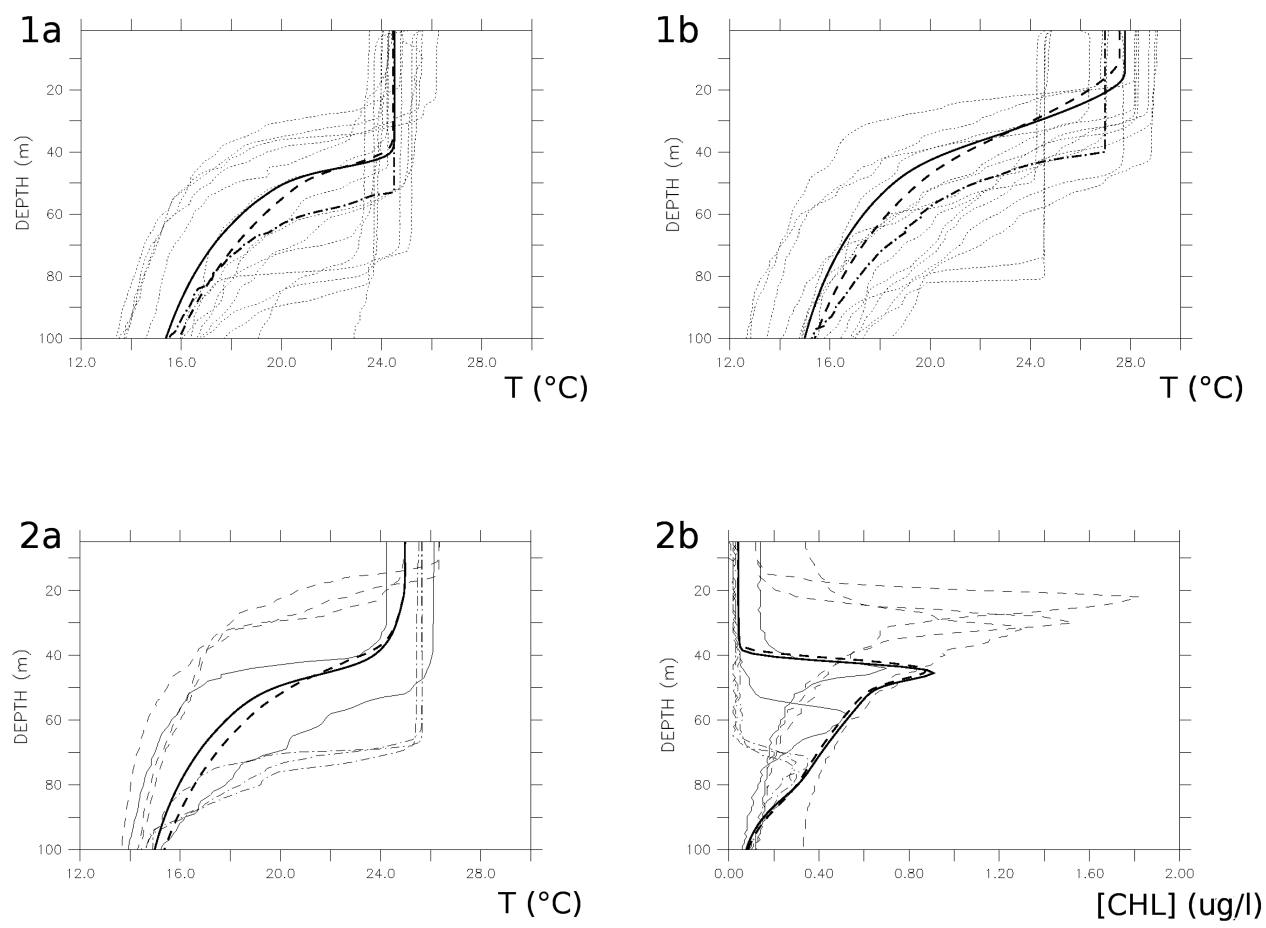

Figure 2. Bold black: CHLDEEP profile. Long dashes: CHLSURF profile. (1) High resolution XBT and CTD data from NODC in Spring (a) and Autumn (b) in the box $10-14^{\circ} \mathrm{N} / 22-30^{\circ} \mathrm{W}$. Long dashes-dots: reconstructed median observation profile. Dots: individual observation profiles. (2) temperature (a) and chlorophyll (b) XBT AMT data in May. Long dashes: three observations where thermocline is the shallowest. Long dashes-dots: three observations where the thermocline is the deepest. Black: other observation profiles.

\section{Model validation}

\section{a. Comparison with in situ temperature data}

Validation of the model temperature distribution (CHLDEEP or CHLSURF) is made versus in situ data from the World Ocean Database 2001 (Fig. 2). We found 65 high resolution (1 m) CTD or XBT profiles since 1970 until 2001 in the GD zone, defined as a box extending from $10^{\circ} \mathrm{N}$ to $14^{\circ} \mathrm{N}$ and $20^{\circ} \mathrm{W}$ to $30^{\circ} \mathrm{W}$. This zone is relatively large, because of the variability and the uncertainty of the GD position. In observations, the mixed layer range is from 30 to $80 \mathrm{~m}$. The profiles with the deepest ML may not be associated with the doming itself; nevertheless we decided to use them in the validation dataset, as objective discrimination is difficult.

Due to the great variability of the ML depth in the GD zone, a classical average of the in situ data versus depth does not reproduce a likely realistic profile for each season: indeed, the result would be a smoothed profile, as typically found in climatologies such as the World Ocean Atlas, which would not reproduce the thermocline gradient. Each in situ 
profile has been divided into two parts: the ML, where temperature is constant, and the deeper ocean below. The discrimination is made at the depth corresponding to De Boyer Montegut et al. (2004) thermocline depth criterion; i.e., the depth reached by the temperature at $10 \mathrm{~m}$ minus $0.2^{\circ} \mathrm{C}$. For each season, we averaged the value of this depth, as well as its temperature. Below this upper layer, the profile has been completed by the average of the deeper ocean value, using the upper thermocline as a depth reference point. The resulting green curve is a mean profile which better represents the characteristic vertical gradient of the field data.

As in the observations, the upper thermocline in the model is deepest in winter (55 m) and shallowest in summer $(35 \mathrm{~m})$, when doming occurs. Whatever the season considered, the mean observed thermocline gradient is about $0.5^{\circ} \mathrm{C} \mathrm{m}^{-1}$ at its steepest location. It is nevertheless possible to observe steeper gradient in some profiles in summer, when the upper thermocline is very close to the surface, from 10 to $25 \mathrm{~m}$. Some other profiles also present steep thermoclines at depth, especially in winter and autumn. Comparing these 'mean' profiles with the CHLDEEP and CHLSURF experiment shows that observations are always deeper by $10-15 \mathrm{~m}$ at the thermocline level. The reason may be the variability of the GD position and strength, as explained above: indeed, the observations may or may not have been realized exactly in the dome (typically a $2^{\circ}$ longitude $\times 2^{\circ}$ latitude feature), whereas the model experiment point has been chosen from model climatological data, exactly in the region where doming is the most effective.

It is noteworthy that the CHLDEEP temperature gradient below the thermocline is stronger than that of the CHLSURF and resembles the observation data more than the CHLSURF experiment, suggesting that the effect of chlorophyll profile is worth being included in ocean models.

\section{b. Comparison with in situ fluorescence data}

Model outputs have been compared with fluorescence profiles from AMT (Robins and Aiken, 1996). The AMT crosses the Atlantic Ocean meridionally twice a year, in spring and autumn. Fluorescence data have been used rather than chlorophyll bottle data as they offer much higher vertical resolution. The conversion into chlorophyll concentration has been made using a statistical algorithm developed by the AMT team. We selected the stations sampled in the GD zone. Temperature and chlorophyll concentration is highly variable. The presence of a DCM coupled with the thermocline had been described in observations all over the tropical Atlantic (Dandonneau, 1979): it is the so-called Typical Tropical Structure (Herbland and Voituriez, 1979). This structure has also been observed in Agusti and Duarte's study (1999) that used field data from Atlantic Meridional Transect (AMT) cruises.

In spring, the three profiles with the shallowest thermoclines are the most noteworthy: two of them have been realized around $10^{\circ} \mathrm{N}$ and $21^{\circ} \mathrm{W}$ at the end of May (2000), the other one has been realized at $11.5^{\circ} \mathrm{N} / 20^{\circ} \mathrm{W}$ at the end of April (1999). These positions are near the position of the GD center as described by Siedler et al. (1992), which is $10^{\circ} \mathrm{N} / 22^{\circ} \mathrm{W}$ in 
winter. Inversely the three profiles presenting the deepest thermocline were made in May 2004 , around $11^{\circ} \mathrm{N} / 29^{\circ} \mathrm{W}$, far away from the GD center. Comparisons of the temperature and the chlorophyll profile show a strong influence of the upper thermocline depth on DCM magnitude. In the most favorable case, i.e. near the GD, the chlorophyll concentration reaches $1.8 \mu \mathrm{g} \mathrm{l}^{-1}$ at $25 \mathrm{~m}$ depth. At the annual scale, the chlorophyll surface value range is from $0.04 \mu \mathrm{g} \mathrm{l}^{-1}$ to $0.12 \mu \mathrm{g} \mathrm{l}^{-1}$ with an outlier point of $0.35 \mu \mathrm{g} \mathrm{l}^{-1}$ which could be caused by advection of a coastal upwelling filament from Cape Verde upwelling.

The mean observed surface chlorophyll is in the same range of values as the mean CHLDEEP and CHLSURF surface chlorophyll. The chlorophyll difference between the two experiments is weak with regards to the in situ variability. It presents a DCM correlated with the thermocline, with a maximum value of about $1 \mu \mathrm{g} 1^{-1}$. The CHLDEEP and CHLSURF vertical shape is in agreement with the field observations, with a coherent DCM concentration in relation to its depth. These values are consistent with the statistical relation established by Agusti and Duarte (1999) between thermocline depth and DCM concentration.

\section{Results and discussion: temperature}

In order to quantify the DCM impact on temperature, we first describe the main features of the CHLSURF seasonal cycle (4a), which we consider as our reference experiment. To give a better explanation of this seasonal cycle, the CHLSURF total temperature evolution term $(\partial T / \partial t)$ is decomposed into its main components $(4 \mathrm{~b})$, which are vertical terms (advection and diffusion/entrainment) and forcing terms (solar and non solar forcing). Next, we compare the CHLDEEP seasonal cycle with the CHLSURF one (4c). As explained before, a full chlorophyll profile is used to compute irradiance in CHLDEEP. This profile is described in Section 5. Temperature difference between CHLDEEP and CHLSURF are then explained by the differences between the terms in the temperature equation evolution between the two experiments (4d).

\section{a. CHLSURF temperature annual cycle}

ML (criterion is $0.01 \mathrm{~kg}^{-3}$ difference from surface) is the coolest in February. Its temperature is then $24.2^{\circ} \mathrm{C}$ and its thickness is $40 \mathrm{~m}$ (Fig. 3). From February to June, ML becomes shallower (detrainment period) due to an increase in solar radiation, a decrease of wind energy input (which becomes negligible in June) and an increase of buoyancy flux. The ML depth reaches its shallowest position from June to October (10 m). ML temperature rises as its thickness decreases: the surface temperature peaks in September, with a maximum value of $28.5^{\circ} \mathrm{C}$. In early October, wind mixing increases, surface radiation decreases and buoyancy flux decreases causing a deepening of the ML (entrainment period) from $10 \mathrm{~m}$ to $40 \mathrm{~m}$, until February next year. ML temperature decreases progressively. The ML is separated from the deeper ocean by a relatively strong permanent thermocline, which presents a maximum thermal gradient of $-0.3^{\circ} \mathrm{C} \mathrm{m}^{-1}$. A seasonal 

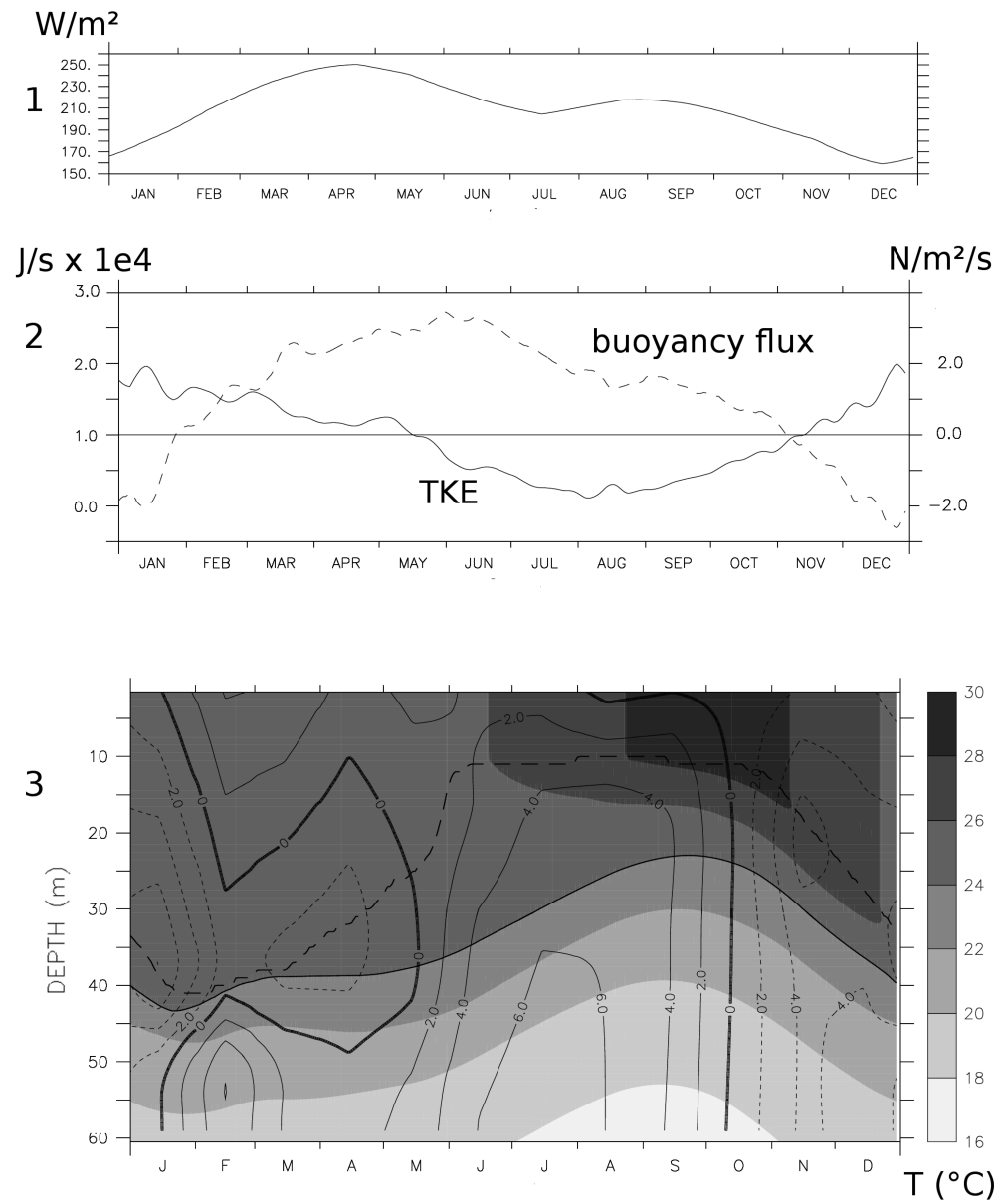

Figure 3. (1) solar surface irradiance $\left(\mathrm{Wm}^{-2}\right)$. (2) surface Turbulent Kinetic Energy $\left(\mathrm{J} \mathrm{s}^{-1}\right) \times 10^{4}$ (black) and buoyancy flux $\left(\mathrm{Nm}^{-2} \mathrm{~s}^{-1}\right) \times 10^{5}$ (dashes). Buoyancy flux has been computed as

$$
B=\frac{g \alpha}{C w} Q_{\text {surf }}+g \beta S(P-E)
$$

$\alpha, \beta$ are thermal and saline coefficients. $Q_{\text {surf }}$ is the sum of heat surface fluxes. $C w$ is the specific heat capacity of water. $E$ is evaporation. $P$ is precipitation. $S$ is salinity at surface. (3) vertical velocity $\left(\mathrm{m}\right.$ month $\left.{ }^{-1}\right)$. contour: CHLSURF isotherms $\left({ }^{\circ} \mathrm{C}\right)$. An isotherm has been traced for each two degree. Isotherms $24^{\circ} \mathrm{C}$ have been traced in bold. The ML has been traced in dashes.

thermocline is created in boreal summer, which extends to the base of the ML down to the $24^{\circ} \mathrm{C}$ isotherm corresponding to the ML's greatest depth in February: the layer extending between these two boundaries is directly ventilated by contact with the atmosphere at least once a year. A barrier layer exists from September to February; a common feature in the tropical oceans (De Boyer Montegut et al., 2004, 2007; Mignot et al., 2007) and is mainly 


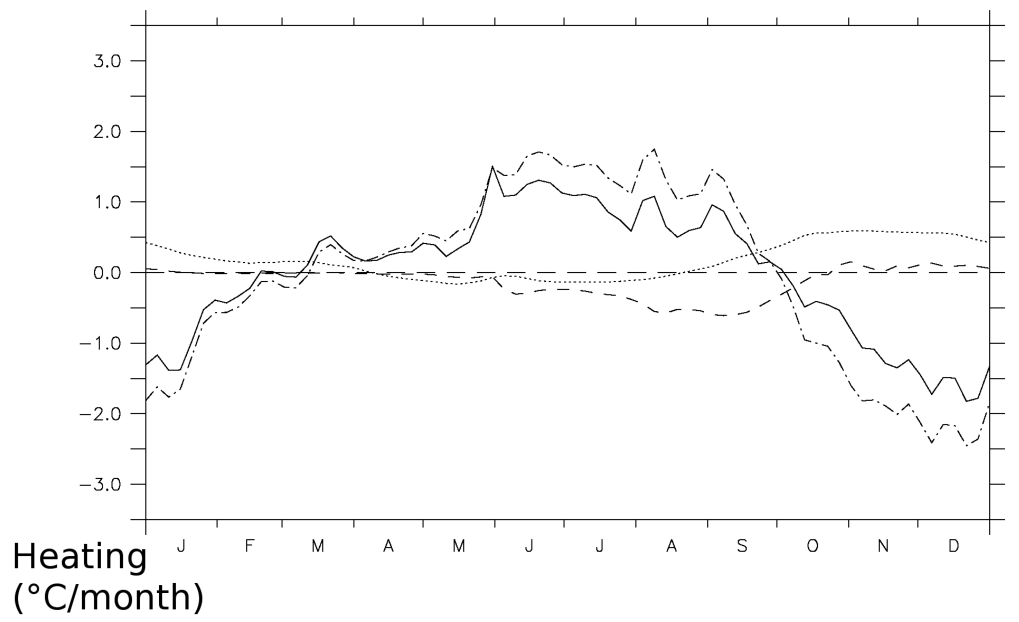

Figure 4. CHLSURF temperature evolution terms $\left({ }^{\circ} \mathrm{C}\right.$ month $\left.^{-1}\right)$ in the ML. black: total trend. Long dashes - dots: atmospheric forcing (solar + turbulent) term. Long dashes: vertical diffusion term. Dots: climatological horizontal term.

caused by precipitation. It is characterized by a temperature inversion compensated in density below the ML; its amplitude is small (thickness of $2 \mathrm{~m}$ and maximal gradient of $+0.05^{\circ} \mathrm{C} \mathrm{m}^{-1}$ ). At the permanent thermocline level, doming occurs from February to October, with vertical velocities reaching $7 \mathrm{~m} \mathrm{month}^{-1}$ in July. Upper permanent thermocline depth shallows from $45 \mathrm{~m}$ in February to $30 \mathrm{~m}$ in September. From October to January the doming vanishes progressively due to the downwelling. Such a pattern is in general agreement with GD literature results, obtained through models (Siedler et al., 1992; Yamagata and Lizuka, 1995) and observations (Voituriez, 1981).

\section{b. CHLSURF temperature evolution}

In the ML (Fig. 4), the temperature total evolution term is negative from October to March, reaching $-1.5^{\circ} \mathrm{C}$ month ${ }^{-1}$ in December, and is positive from April to September, reaching $+1.2^{\circ} \mathrm{C}_{\text {month }}{ }^{-1}$ in June and July. Globally, there is a good agreement between the total term and the forcing term. These results are in agreement with previous studies, which have found that, in tropical Atlantic ML, the major cause of seasonal variability is caused by the seasonal cycle of atmospheric forcing (Foltz et al., 2003). Vertical diffusion cools the ML by $0.5^{\circ} \mathrm{C}$ month $^{-1}$ from June to September. It warms the ML by a maximum of $0.1^{\circ} \mathrm{C}$ month ${ }^{-1}$ from October to February while a temperature inversion is present at the ML base. A strong decay in surface forcing occurs from late September (maximum of $-2.6^{\circ} \mathrm{C}$ month ${ }^{-1}$ in November). This decay is caused by the solar heat flux decrease and the increase of heat loss by non penetrative heat fluxes, correlated with higher surface TKE (Fig. 3). The result is a negative total temperature evolution (cooling): the convective overturning intensifies, which causes the ML deepening from September/ 

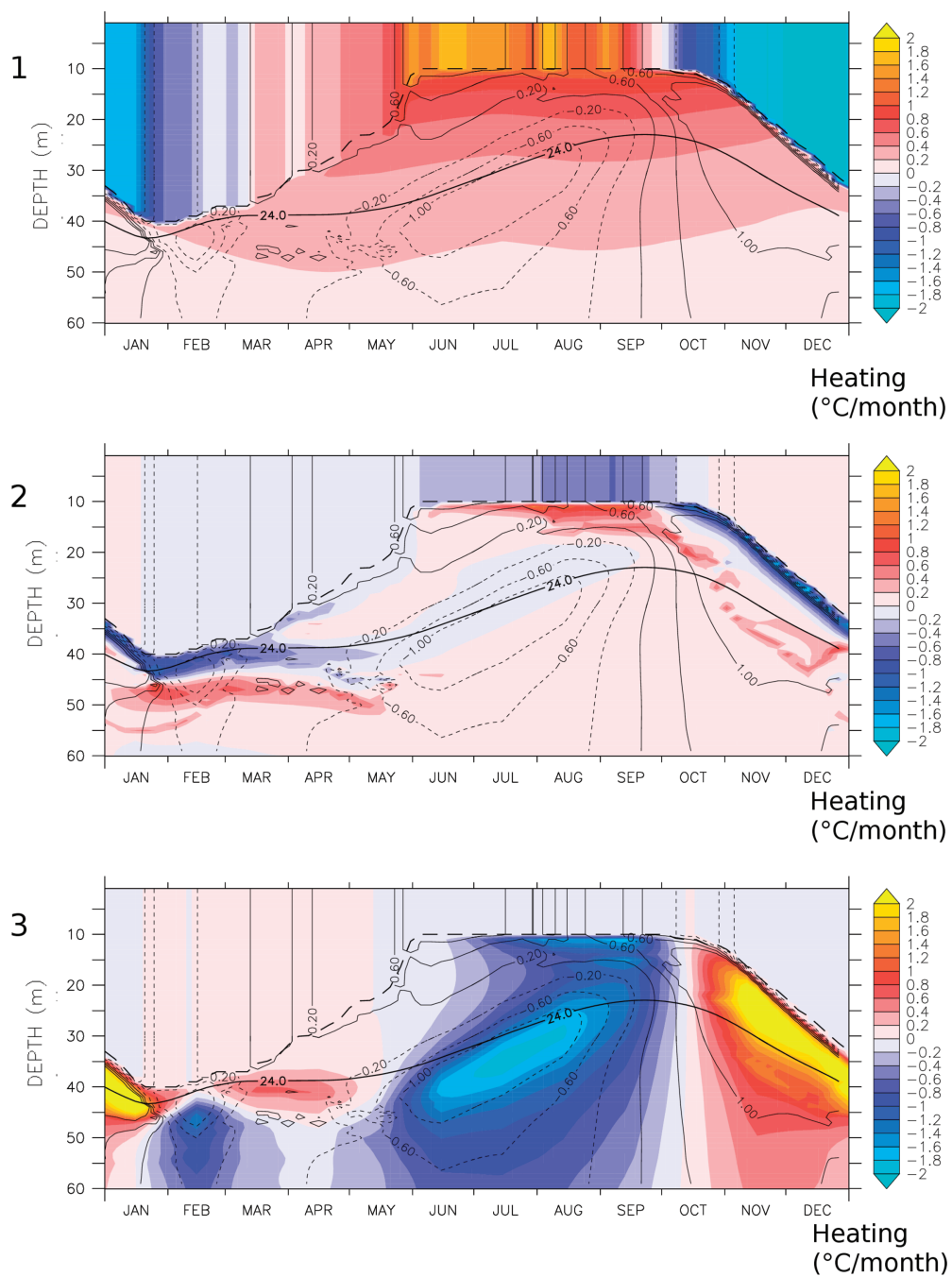

Figure 5. CHLSURF temperature evolution terms $\left({ }^{\circ} \mathrm{C}\right.$ month $\left.{ }^{-1}\right)$ below and mean in the ML. ML has been masked and replaced by mean values. For each subFig., the isoline $24^{\circ} \mathrm{C}$ has been represented in bold. The total trend has been traced as contour. (1) heat transfered by solar radiations and exchange with atmosphere. (2) vertical diffusion term. (3) vertical advection term.

October to December. In December, the convective entrainment of deeper warm water stabilizes the ML.

Below the ML (Fig. 5), in the seasonal thermocline (defined as the zone extending between the base of the $\mathrm{ML}$ and the $24^{\circ} \mathrm{C}$ isotherm), the temperature total evolution term is slightly negative in January-February $\left(-0.5^{\circ} \mathrm{C}\right.$ month $\left.^{-1}\right)$ and is mainly due to the vertical upwelling of cold water. The solar heating term is weak (maximum of $0.5^{\circ} \mathrm{C}$ month ${ }^{-1}$ ) till 
July, as the base of the ML is deep (40 m). When the ML base shallows in June, the forcing term becomes more important. It reaches $+1^{\circ} \mathrm{C}$ month ${ }^{-1}$ from July to September when the ML base is the shallowest $(10 \mathrm{~m})$. At the same time, the vertical transport becomes important due to the strong upwelling (Fig. 3) that occurs during this season $\left(-1.2^{\circ} \mathrm{C}\right.$ month $\left.{ }^{-1}\right)$. Until September, the deep ocean transport counter-acts the solar heating term; the total temperature term is small. In September and October, the ML deepens: the solar heating trend is getting smaller whereas the total temperature trend is becoming more important $\left(+1.6^{\circ} \mathrm{C} \mathrm{month}^{-1}\right)$. Vertical advection warms the seasonal thermocline, via the downwelling of warm water from the ML. At the same time, diffusion cools a 2-m thin layer located just below the ML, due to the presence of a density compensated temperature inversion.

Below the seasonal thermocline, at the top of the annual thermocline (from the $24^{\circ} \mathrm{C}$ isotherm to $100-\mathrm{m}$ depth), the total temperature trend is strongly correlated with the vertical transport trend and the vertical velocity. The temperature trend is negative during periods of cold water upwelling from February to October, (maximum trend of $-0.6^{\circ} \mathrm{C}$ month $^{-1}$ ) and positive during downwelling of the upper warm water from October to January (maximum trend of $+1{ }^{\circ} \mathrm{C}$ month ${ }^{-1}$ ). The solar heating trend value is about $+0.1^{\circ} \mathrm{C}$ month $^{-1}$ all year long.

\section{c. CHLDEEP minus CHLSURF temperature differences}

In the seasonal thermocline, CHLDEEP temperature is greater by about $+0.3^{\circ} \mathrm{C}$ to $+2^{\circ} \mathrm{C}$ during the upwelling season, with a maximum in October between 15-m and 20-m depth. A strong correlation exists between the presence of deep chlorophyll and the temperature anomaly location (Fig. 6). The upper seasonal thermocline is less stratified in CHLDEEP than in CHLSURF: the vertical gradient is $-0.2^{\circ} \mathrm{C} \mathrm{m}^{-1}$ in September at $15 \mathrm{~m}$ for CHLDEEP and $-0.35^{\circ} \mathrm{C} \mathrm{m}^{-1}$ for CHLSURF. The CHLDEEP seasonal thermocline is slightly deeper by a few meters for CHLDEEP than for CHLSURF; its characteristic isotherm is also $24^{\circ} \mathrm{C}$. The temperature inversion is more visible in CHLDEEP with a maximum vertical gradient of $+0.1^{\circ} \mathrm{C} \mathrm{m}^{-1}$ in early October at $5 \mathrm{~m}$ (maximum of $0.05^{\circ} \mathrm{C}$ $\mathrm{m}^{-1}$ in CHLSURF). However, the water column is less stratified in density below the ML in CHLDEEP. This feature has an important impact on vertical diffusion (see 4.d). Inversely, the water column is more stratified in the CHLDEEP permanent thermocline with values of $-0.55^{\circ} \mathrm{C} \mathrm{m}^{-1}$ in CHLDEEP and $-0.35^{\circ} \mathrm{C} \mathrm{m}^{-1}$ in CHLSURF at $30 \mathrm{~m}$ in September. This feature is present with the same intensity throughout the whole year. In the permanent thermocline, temperatures are lower in CHLDEEP than in CHLSURF, with a maximum difference of about $-1.2^{\circ} \mathrm{C}$ at $40 \mathrm{~m}$ (upwelling season) and $-1.5^{\circ} \mathrm{C}$ at $50 \mathrm{~m}$ (downwelling season). The temperature difference is attenuated progressively with depth.

The ML temperature is higher in the CHLDEEP experiment from August to March. This difference reaches $+0.27^{\circ} \mathrm{C}$ in early November and progressively decreases from November to the end of March. There is no ML temperature difference between the two experiments from April to September. The ML base is slightly deeper in 

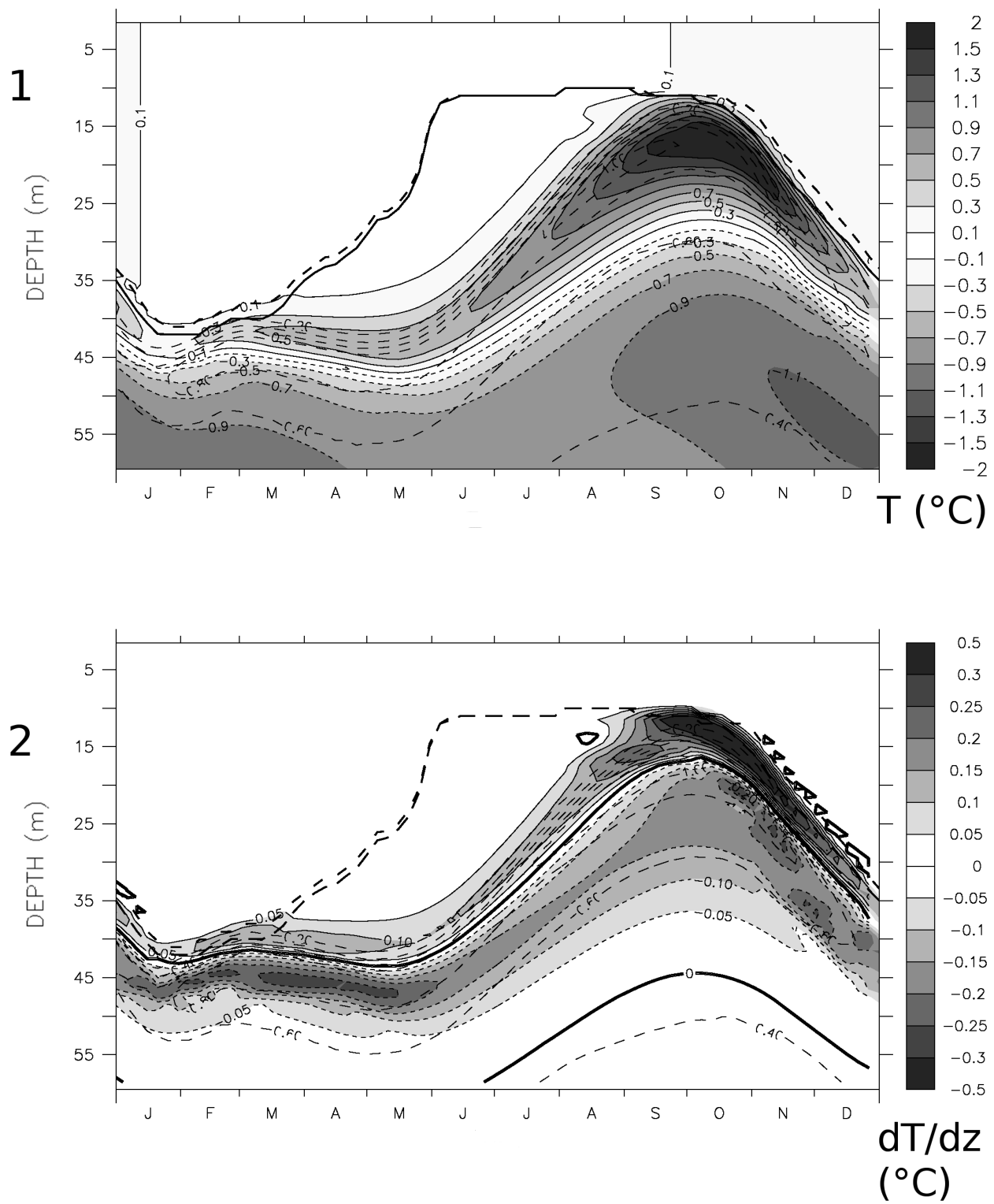

Figure 6. The CHLSURF ML (bold black), CHLDEEP ML (bold dashes) and CHLDEEP chlorophyll vertical profile have been traced in contour $\left(\mu \mathrm{g} 1^{-1}\right)$. (1) CHLDEEP minus CHLSURF temperature $\left({ }^{\circ} \mathrm{C}\right)(2)$ CHLDEEP minus CHLSURF temperature gradient $\left({ }^{\circ} \mathrm{C}\right.$ meter $\left.{ }^{-1}\right)$.

CHLDEEP for the annual mean. The maximal ML depth difference occurs at the beginning of November and reaches $2 \mathrm{~m}$ in CHLDEEP $(+20 \%)$. The depth difference between the CHLDEEP and the CHLSURF ML base progressively decreases after 

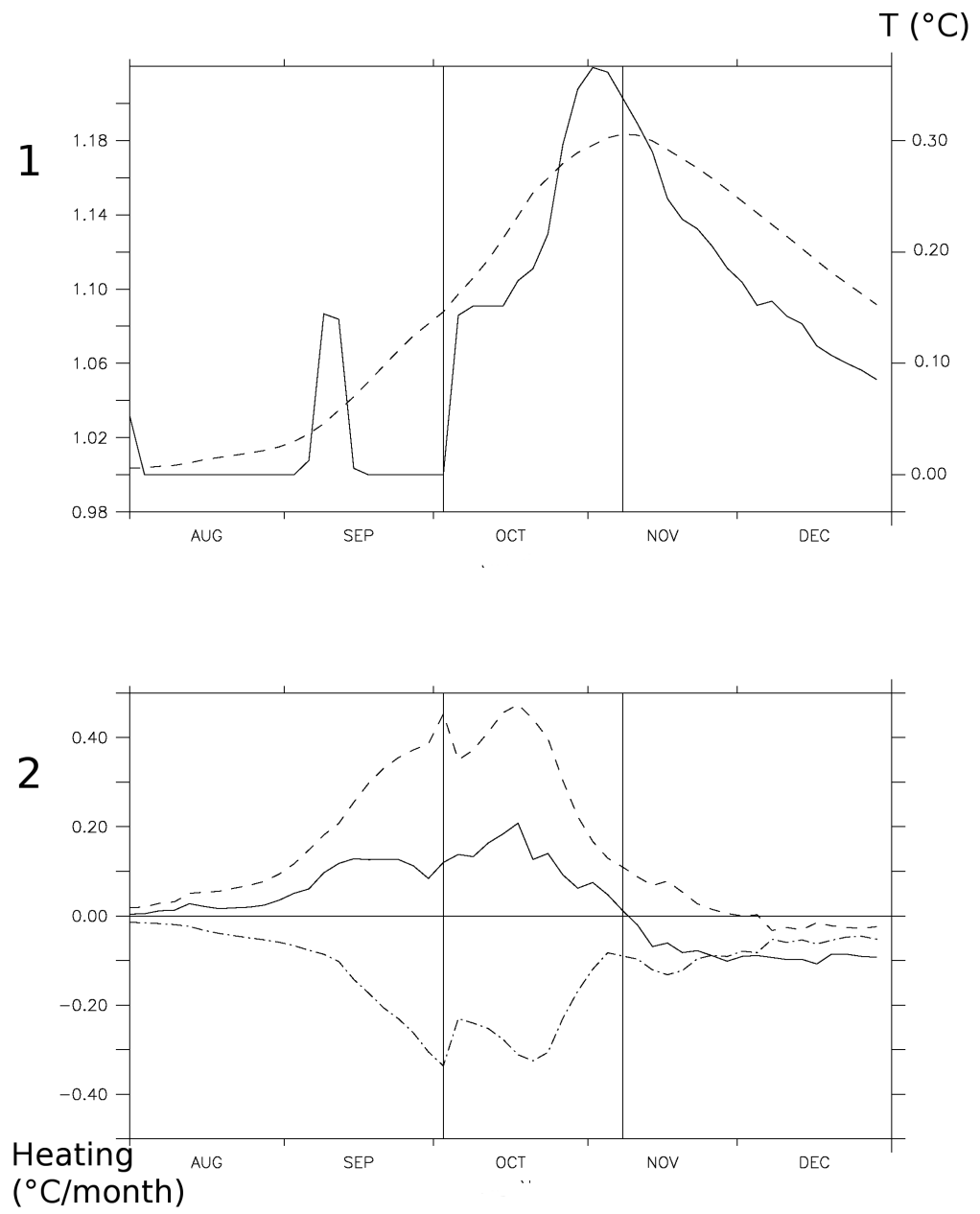

Figure 7. (1) black: CHLDEEP over CHLSURF ML depth. dashes: CHLDEEP minus CHLSURF ML temperature $\left({ }^{\circ} \mathrm{C}\right) ;(2) \mathrm{ML}$ temperature evolution term $\left({ }^{\circ} \mathrm{C}_{\text {month }}{ }^{-1}\right)$. black: CHLDEEP minus CHLSURF total term. dashes: CHLDEEP minus CHLSURF vertical diffusion term. Dashes-dots: CHLDEEP minus CHLSURF atmospheric forcing (solar + turbulent) term.

February, when the ML base is at its deepest position. The ML base is located at the same depth from June to September.

\section{d. CHLDEEP minus CHLSURF temperature breakdown terms}

Below the ML, in the seasonal thermocline, (Fig. 8), the main difference between CHLDEEP and CHLSURF occurs from July to October. In this period CHLDEEP temperature is greater by $2^{\circ} \mathrm{C}$ above the DCM and lower by $1^{\circ} \mathrm{C}$ below. The warming is due to an increase of the forcing (solar) term (Fig. 3) from July by $+1^{\circ} \mathrm{C}$ month ${ }^{-1}$ in 

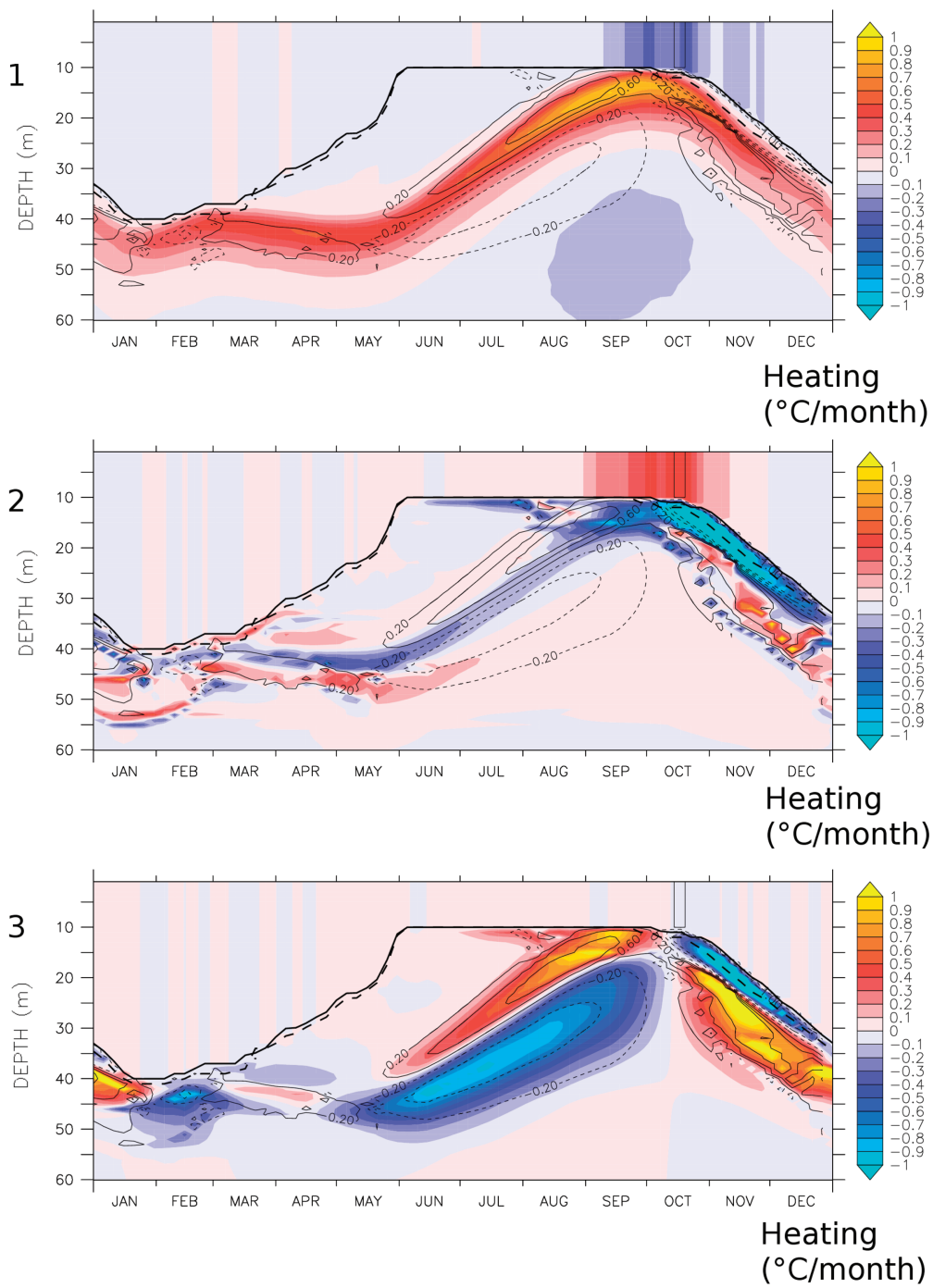

Figure 8. CHLDEEP minus CHLSURF temperature evolution terms $\left({ }^{\circ} \mathrm{C}\right.$ month $\left.{ }^{-1}\right)$ below and mean in the ML. ML has been masked and replaced by its mean value. The CHLSURF ML (bold black), CHLDEEP ML (bold dashes) have been traced. The total CHLDEEP minus CHLSURF trend has been traced as contour. (1) CHLDEEP minus CHLSURF heat transfered by solar radiations. (2) CHLDEEP minus CHLSURF vertical diffusion term. (3) CHLDEEP minus CHLSURF vertical advection term.

CHLDEEP. This increase is caused by the DCM presence in CHLDEEP, which has an impact on heat absorption (see Optical Model). From October to December, the DCM causes a cooling by diffusion just below the ML associated with a density compensated temperature inversion. Indeed, in CHLDEEP the temperature inversion is less stratified in 
density as the seasonal thermocline is more homogeneous. Relations between DCM and temperature inversion evolution will need to be further investigated in a future study.

Below the DCM, the forcing trend decreases by $-0.1^{\circ} \mathrm{C} \mathrm{month}^{-1}$ due to light absorption in the upper water column. The result of this differential heating is the increase of stratification at the DCM level, by $0.3^{\circ} \mathrm{C} \mathrm{m}^{-1}$, which in turn has an impact on vertical advection whose absolute value can increase by $1^{\circ} \mathrm{C}$ month ${ }^{-1}$ in CHLDEEP either during upwelling or during downwelling periods. Differences in temperature between CHLDEEP and CHLSURF are then related directly to heat capture by the DCM. Vertical advection is also modulated by gradient intensification. These two mechanisms have the same order of magnitude.

In the ML, the main difference between CHLDEEP and CHLSURF occurs in October when the CHLDEEP experiment is warmer by $0.3^{\circ} \mathrm{C}$. The mechanism, which leads to this ML temperature anomaly, can be decomposed into three steps (Fig. 7):

From the beginning of August to October $3^{\text {rd }}$, vertical diffusion increases by $+0.4^{\circ} \mathrm{C}$ month $^{-1}$ in CHLDEEP when compared with CHLSURF. This vertical diffusion increase may be caused by weaker stratification of the seasonal thermocline below the ML in CHLDEEP. Indeed, phytoplankton heats the seasonal thermocline, reducing the temperature and the density gradients between the seasonal thermocline and the ML. The water then becomes more homogeneous which increases the diffusion coefficient. Non solar heat fluxes are reacting to this CHLDEEP SST increase, as the forcing trend, already negative, decreases in CHLDEEP by -0.1 to $-0.3^{\circ} \mathrm{C}$ month ${ }^{-1}$. The effect of these two antagonist mechanisms is an increase by $0.05^{\circ} \mathrm{C}$ of the SST in CHLDEEP. ML depth is $10 \mathrm{~m}$ for both cases CHLDEEP and CHLSURF, and thus has no effect on CHLDEEP - CHLSURF ocean-atmosphere fluxes.

From October $3^{\text {rd }}$ to November $8^{\text {th }}$, the ML starts to deepen due to the destabilization of the upper water column, the increase of kinetic energy transfer by winds (Fig. 3), and buoyancy loss. ML deepens faster in CHLDEEP than in CHLSURF due to the weaker stratification of the CHLDEEP water column below the ML. The ratio between CHLDEEP ML and CHLSURF ML is the greatest on November $8^{\text {th }}$ as CHLDEEP ML is $20 \mathrm{~m}$ and CHLSURF ML is $16 \mathrm{~m}$. Warmer water is entrained in CHLDEEP than in CHLSURF due to seasonal thermocline heating: the result is an SST increase, damped by the ocean atmosphere heat fluxes. However, the heat gained by entrainment/diffusion is greater than the heat loss by damping. Another effect needing consideration is the impact of ML deepening as ML fluxes are modulated by the ML depth. As ML depth is greater in CHLDEEP, positive diffusive and negative diffusive trends are diluted, which explains why the fluxes trends are not correlated anymore with SST in contrast to what was observed in the first step.

From November $8^{\text {th }}$, the ML continues to deepen reaching more than $30 \mathrm{~m}$ on December $15^{\text {th }}$ in CHLSURF and CHLDEEP. The CHLDEEP - CHLSURF heat entrainment becomes less important as the difference between CHLDEEP and CHLSURF temperature 
at the ML base decreases in November. As CHLDEEP ML is warmer, the CHLDEEP damping due to ocean atmosphere turbulent forcing fluxes is stronger; the vertical diffusion trend is not strong enough to compensate for this damping: the net effect is then a cooling of the CHLDEEP ML. The SST anomaly in CHLDEEP progressively decreases, but persists until February next year.

\section{Results and discussion: biogeochemical tracers}

Nitrate is depleted in the CHLSURF ML, with an annual mean concentration of $10^{-4} \mu \mathrm{M}$ which is below the actual detection limit $\left(0.210^{-3} \mu \mathrm{M}\right)$. On the mean, Nitrate concentration is almost double in CHLDEEP than in CHLSURF due to a $310^{-3} \mu \mathrm{M}$ nitrate peak in October, whereas nitrate concentration is only $110^{-3} \mu \mathrm{M}$ in CHLSURF during the same period (Fig. 9). The nitracline can be defined as the depth where chlorophyll concentration starts to increase. It is correlated with the $0.02 \mu \mathrm{M}$ nitrate isopleth in both experiments. In October, the ML reaches the nitracline depth in CHLDEEP, causing an entrainment of nitrate by $0.17 \mu \mathrm{M}$ month $^{-1}$. During the same period, in CHLSURF, the ML is separated from the nitracline by a few meters. Entrainment is an important mechanism as it can better explain the presence of nitrate in the ML, especially if it is transposed to subpolar gyre regions where the autumn bloom is mainly fueled by nutrients entrained in the ML. Below the nitracline, nitrate concentration is globally correlated with temperature, as shown by several authors (Voituriez and Herbland, 1983; Chavez et al., 1996). In the CHLDEEP experiment, nitrate ranges from nearly 0 at the surface to $26 \mu \mathrm{M}$ at 100-m depth. These values are comparable to the values found by the authors cited above. Nitrate difference between CHLDEEP and CHLSURF is small at depth.

The annual mean of CHLSURF chlorophyll concentration is $0.05 \mu \mathrm{g}^{-1}$ in the ML. Chlorophyll concentration reaches $0.05 \mu \mathrm{g}^{-1}$ in February-March and from October to December, when nitrate concentration is higher. The chlorophyll concentration difference follows the same pattern as the nitrate, with a maximal difference between CHLDEEP and CHLSURF in September/October where concentrations are greater by $0.02 \mu \mathrm{g} 1^{-1}$ $(+50 \%)$. Like nitrate, phytoplankton cells are entrained in the ML. There is nevertheless not enough nitrate entrained to entail a strong surface 'bloom'. Below the ML, chlorophyll concentration is characterized by a DCM present throughout the year. Its depth is determined by the availability of light and nutrients. It has been shown that the most favorable zone for phytoplankton growth corresponds to the zone of maximal stability, i.e. the zone where density gradient (which can be approximated by temperature gradient) is strongest (Agusti and Duarte, 1999). The highest chlorophyll values are located near the upper permanent thermocline. Chlorophyll concentration decreases beneath the DCM until quasi null values are found deeper than 110 or $120 \mathrm{~m}$. The maximal CHLDEEP chlorophyll concentration varies from $0.7 \mu \mathrm{g}^{-1}$ in December to $1.1 \mu \mathrm{g} \mathrm{l}^{-1}$ in August/September, when the DCM is located at its shallowest position (20 m). In CHLDEEP annual mean values are weaker in comparison to CHLSURF by $0.1 \mu \mathrm{g}{ }^{-1}$. 

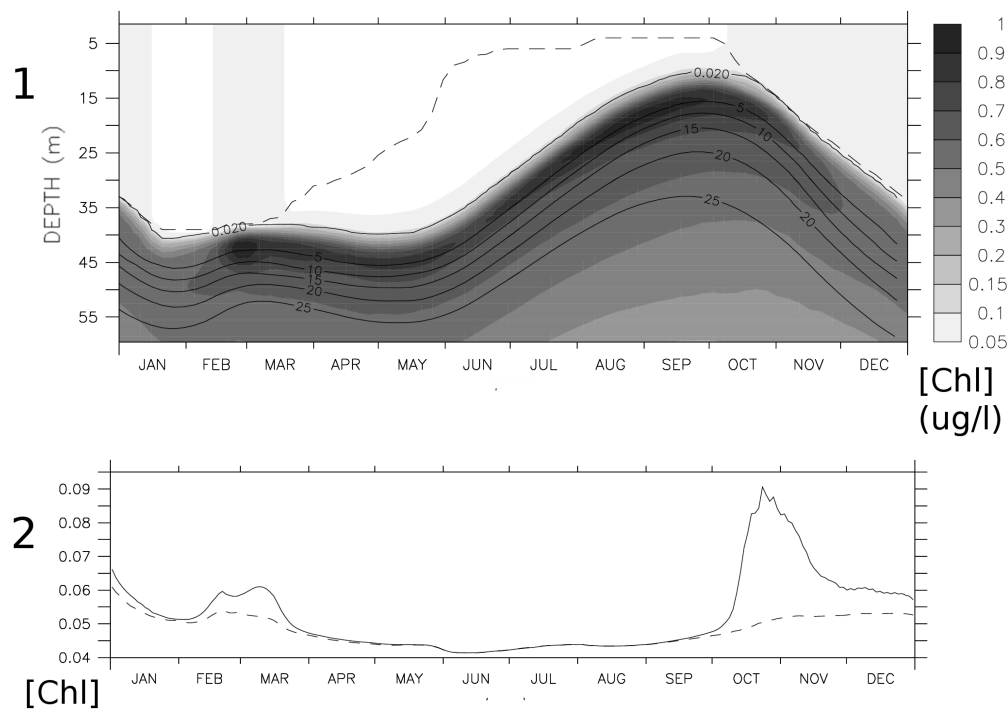

(ug/l)

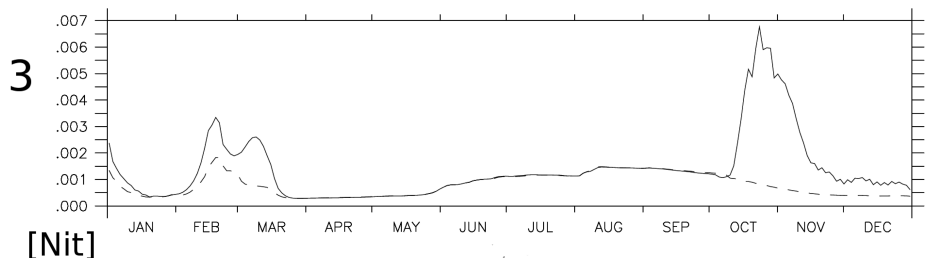

(uM)

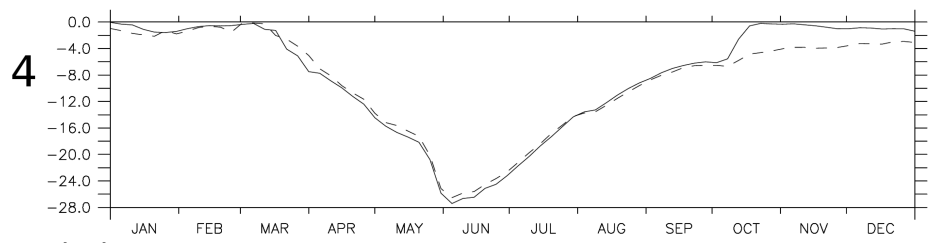

$z(m)$

Figure 9. (1) CHLDEEP chlorophyll concentration $\left(\mu \mathrm{g} \mathrm{l}^{-1}\right)$. contour: nitrate concentration $(\mu \mathrm{M})$ isolines; (2) CHLDEEP (black) and CHLSURF (dashes) nitrate concentration ( $\mu \mathrm{M})$ in the ML; (3) CHLDEEP (black) and CHLSURF (dashes) chlorophyll concentration $\left(\mu \mathrm{g} 1^{-1}\right)$ in the ML; (4) ML depth-nitracline depth (depth where nitrate concentration is equal to $0.02 \mu \mathrm{M}$ ) for CHLDEEP (black) and CHLSURF (dashes).

Primary production (PP) has been integrated in three different ways; over the whole water column, in the ML only, or in the thermocline only (Table 2). In CHLDEEP, the PP annual mean in the water column is about $190 \mathrm{gC} \mathrm{m}^{-2} \mathrm{yr}^{-1}$. There is no significant difference with CHLSURF. In both cases, the most productive season is summer, with a mean $\mathrm{PP}$ of $260 \mathrm{gC} \mathrm{m}^{-2} \mathrm{yr}^{-1}$, when growth is favored by the upwelling of nutrient and a greater irradiance at the shallower DCM. The least productive season is winter, averaging 
Table 2. Primary production in the euphotic zone in CHLDEEP and CHLSURF.

\begin{tabular}{lccccc}
\multicolumn{1}{c}{ PP $\left(\mathrm{gC} / \mathrm{m}^{2} / \mathrm{yr}\right)$} & JFM & AMJ & JAS & OND & Annual \\
ML (CHLDEEP/CHLSURF) & $14 / 13$ & $9 / 9$ & $3 / 3$ & $13 / 9$ & $10 / 8.5$ \\
Thermocline (CHLDEEP/CHLSURF) & $114 / 120$ & $136 / 142$ & $260 / 262$ & $202 / 210$ & $178 / 182$ \\
Total (CHLDEEP/CHLSURF) & $128 / 133$ & $145 / 151$ & $263 / 265$ & $215 / 219$ & $188 / 190.5$
\end{tabular}

to $130 \mathrm{gC} \mathrm{m}^{-2} \mathrm{yr}^{-1}$. In the $\mathrm{ML}$, the $\mathrm{PP}$ is about $10 \mathrm{gC} \mathrm{m}^{-2} \mathrm{yr}^{-1}$ and represents $1 \%$ (summer) to $12 \%$ (winter) of the water column integrated PP. These values are in agreement with the study of Herbland and Voituriez (1979). They assessed the value and the percentage of primary production located in the tropical Atlantic ocean nitracline, in relation with nitracline depth. CHLDEEP and CHLSURF concentration are statistically identical, except in autumn when CHLSURF PP is $9 \mathrm{gC} \mathrm{m}^{-2} \mathrm{yr}^{-1}$ and CHLDEEP PP $13 \mathrm{gC} \mathrm{m}^{-2} \mathrm{yr}^{-1}$. This is due to increased nutrient entrainment as well as integration over a deeper ML in CHLDEEP. Below the ML, the CHLDEEP PP is always smaller by a few percent than the CHLSURF PP, which may be explained by the lower irradiance received in CHLDEEP than in CHLSURF, as the ML is deeper in CHLDEEP.

\section{Generalization to others regions}

a. Sensitivity to light availability

To evaluate if the vertical chlorophyll profile could have an impact in regions other than the GD, we tested the impact of a key parameter: the irradiance received by the DCM. To modulate this irradiance, a simple solution is to increase the chlorophyll concentration above the DCM. We made two additional experiments: CHLDEEP' $\mathrm{Cmin}$ ' and

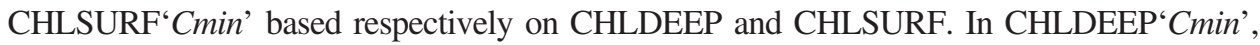
as in CHLDEEP, the PISCES model is used to compute a vertical chlorophyll profile used in the optical model. The difference with CHLDEEP is that in CHLDEEP' $\mathrm{Cmin}$ ' the chlorophyll concentration cannot be lower than a minimal value $\operatorname{Cmin}$ such as $\operatorname{Chl}(z)=$ $\min (\operatorname{Chl}(z), C \min )$. In CHLSURF'Cmin', chlorophyll concentration used in the optical model is set to Cmin in throughout the water column.

We varied $C \min$ values from 0.1 to $1 \mu \mathrm{g}^{-1}$ every $0.1 \mu \mathrm{g} \mathrm{1^{-1 }}$. In all the above experiments, the depth where the chlorophyll vertical gradient is greatest (top of the DCM) does not change (about $25 \mathrm{~m}$ ). At $25 \mathrm{~m}$, the PAR ranges from $20 \%\left(\mathrm{Cmin}=0.1 \mu \mathrm{g} \mathrm{l^{-1 }}\right)$ to $8 \%\left(\mathrm{Cmin}=1 \mu \mathrm{g} \mathrm{l}^{-1}\right)$ of surface irradiance. For all $\mathrm{Cmin}$ values the temperature difference between CHLDEEP ' $\mathrm{Cmin}$ ' and CHLSURF' $\mathrm{Cmin}^{\prime}$ ' is greatest in September. When $\mathrm{Cmin}=0.1 \mu \mathrm{g}^{-1}$, the maximum heating due to $\mathrm{DCM}$ is equal to $+1.8^{\circ} \mathrm{C}$ whereas the maximum cooling is equal to $-1^{\circ} \mathrm{C}$. When $\mathrm{Cmin}=1 \mu \mathrm{g} \mathrm{l}^{-1}$, the DCM impact on temperature is negligible. The DCM has a significant impact when Cmin is lower than $0.4 \mu \mathrm{g} \mathrm{l}^{-1}$ (then, the top of DCM receives more than $10 \%$ of surface radiations or about $20 \mathrm{Wm}^{-2}$ ) (Fig. 10). Stramska and Stramski (2005) showed that the DCM has an impact on 

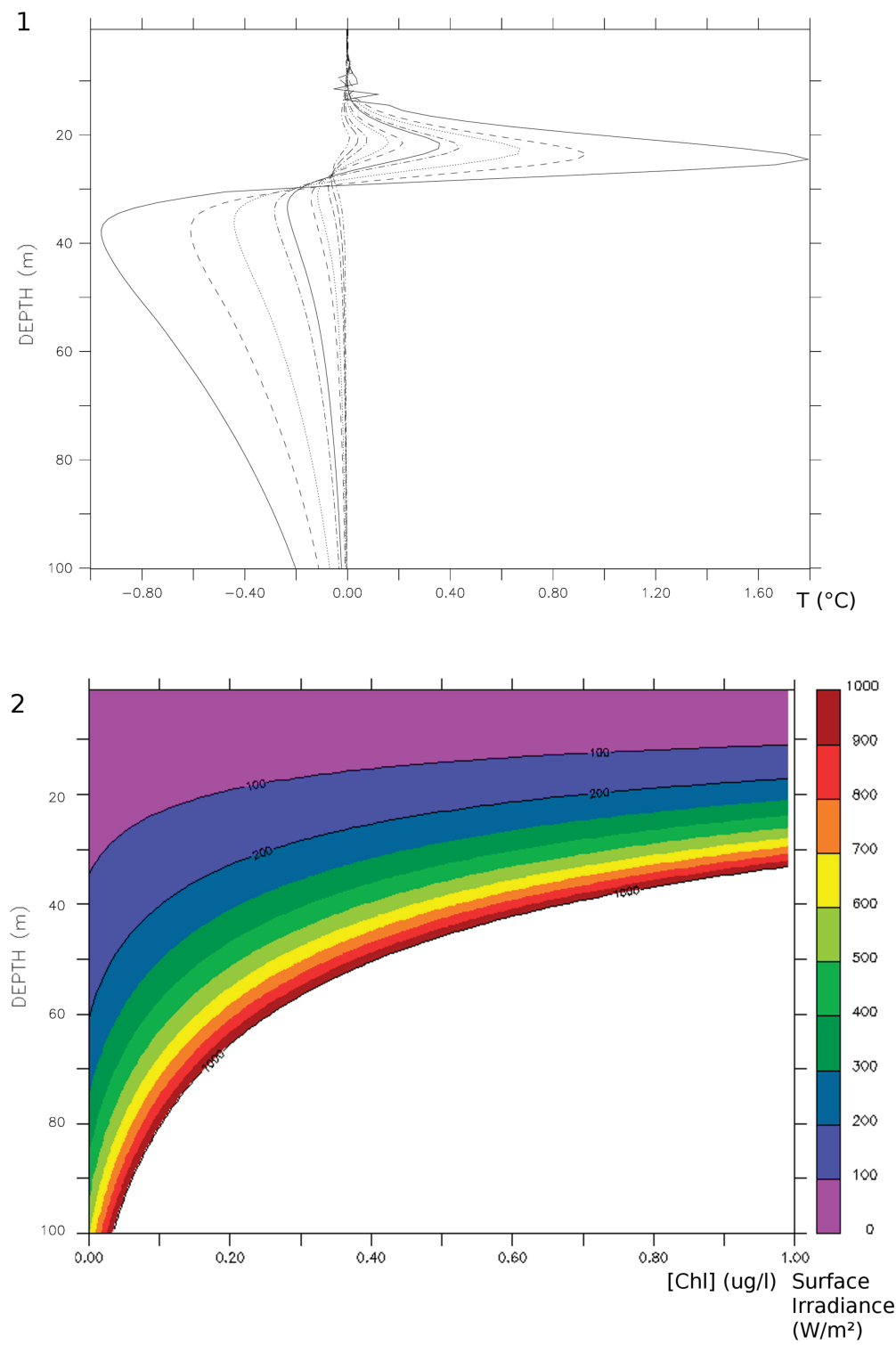

Figure 10. (1) September profile $\left({ }^{\circ} \mathrm{C}\right)$ of $\mathrm{CHLDEEP}{ }^{\prime} \mathrm{Cmin}$ ' minus $\mathrm{CHLSURF}{ }^{\circ} \mathrm{Cmin}$ ' temperature; Surface chlorophyll ' $C \mathrm{~min}$ ' increases from 0.1 to $1 \mu \mathrm{g} \mathrm{l^{-1 }}$ by $0.1 \mu \mathrm{g} \mathrm{l^{-1 }}$ step; (2) Depth (m) of $20 \mathrm{Wm}^{-2}$ irradiance isolines depending of depth $(\mathrm{m})$, surface chlorophyll $\left(\mu \mathrm{g} \mathrm{l}^{-1}\right)$ and surface irradiance $\left(\mathrm{Wm}^{-2}\right)$.

surface ocean reflectance down to a depth of $65 \mathrm{~m}$ when the upper ocean is very oligotrophic (surface chlorophyll of $0.02 \mu \mathrm{g} \mathrm{l}^{-1}$ ), or down to a depth of $20 \mathrm{~m}$ when surface chlorophyll is $0.4 \mu \mathrm{gl}^{-1}$, a value which can be compared to the result obtained here. 

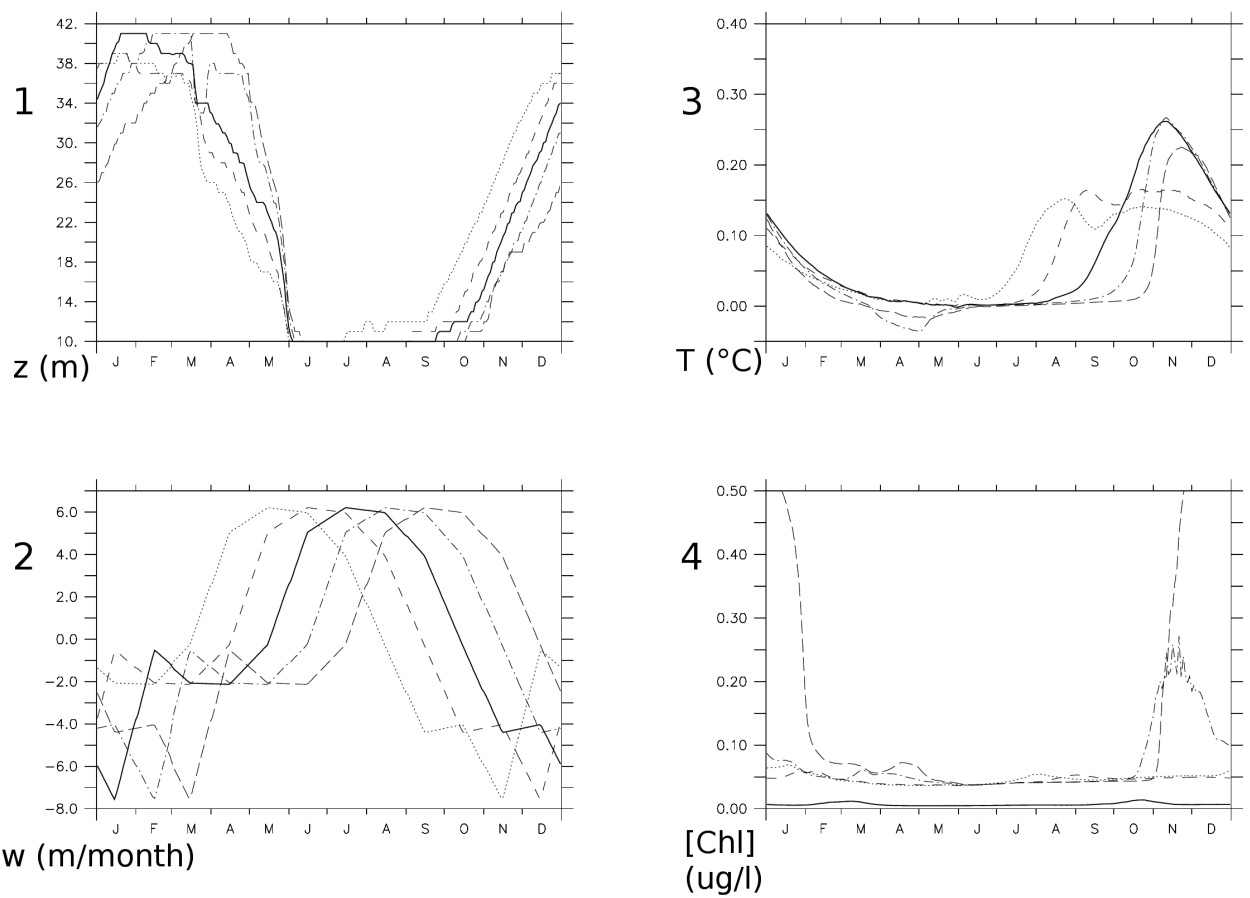

Figure 11. (1) ML (m) depth for CHLDEEP experiments where vertical velocity forcing has been shifted by $-2,-1,0,1,2$ months; (2) vertical velocity profile $\left(\mathrm{m}\right.$ month $^{-1}$ ): temporal shift by -2 , $-1,0,1,2$ months; (3) CHLDEEP - CHLSURF temperature $\left({ }^{\circ} \mathrm{C}\right)$ in the case of a vertical velocity temporal shift by $-2,-1,0,1,2$ months; (4) CHLDEEP chlorophyll $\left(\mu \mathrm{g}^{-1}\right)$ in the case of a vertical velocity temporal shift by $-2,-1,0,1,2$ months.

In terms of irradiance at the DCM level, the surface chlorophyll concentration increase is equivalent to a DCM deepening. We define zIRR20 to be the depth at which an irradiance of $20 \mathrm{Wm}^{-2}$ is encountered. For regions presenting a surface irradiance of $200 \mathrm{Wm}^{-2}$ (a typical annual mean value found in tropical regions or in higher latitude regions during summer), zIRR20 is $25 \mathrm{~m}$ if surface chlorophyll concentration is $0.4 \mu \mathrm{g}^{-1}$ and $50 \mathrm{~m}$ if surface concentration is $0.05 \mu \mathrm{g}^{-1}$ as shown in Figure 11. Occasionally, surface irradiance can reach more than $1000 \mathrm{Wm}^{-2}$ at noon under clear sky conditions. Under such conditions, the zIRR20 is deeper than $100 \mathrm{~m}$ for oligotrophic waters: the DCM may then have an influence on diurnal cycle even in subtropical gyres where the DCM is deep.

\section{b. Sensibility to the upwelling seasonality}

Vertical velocity regulates the nutrient supply to the euphotic zone and controls the nitracline and DCM depths and then the vertical distribution of solar heat trapping. Thus it is crucial to assess the effect of the upwelling seasonality. Indeed, the DCM is likely to 
warm the sea surface when it is shallow. As described in 4.d, the DCM can lead to a warmer ML either by vertical diffusion when there is no deepening of the ML, or by entrainment when the ML deepens. For the DCM to have a maximal effect on SST, upwelling should then occur when the ML is shallow and during the entrainment period.

To test the sensitivity to the upwelling seasonality, the experiments CHLSURF and CHLDEEP were performed again applying a temporal shift to the vertical velocity field (Fig. 11). The velocity field was shifted forward by 1-2 months (then, upwelling is maximum in October when the ML is deepening and downwelling occurs during the restratification period) and 1-2 month backward (then upwelling is maximum in June at the end of the restratification period and downwelling occurs during the entrainment period). Upwelling has a relatively small influence on the ML seasonal cycle, which is mainly forced by atmospheric fluxes (see 4.b). It is interesting to note a correlation between the CHLDEEP - CHLSURF temperature anomaly and the upwelling period: SST warming occurs about one month after the period of the maximal upwelling, even if the ML does not deepen. This warming is due to heat transfer by vertical diffusion. SST warming should be greater when the upwelling occurs during the entrainment period, as the DCM is generally located just below the ML in which case the heat captured is then directly transferred to the ML. It is then surprising to observe the same temperature range anomaly in the standard run and in the experiments where the upwelling is shifted by one to two months forward. However, as surface chlorophyll concentration also increases in these two experiments, the DCM has a less active role, as seen in 6.b. The reason for the ML chlorophyll increase can be due to the nitrate and chlorophyll entrainment.

In summary, to observe the maximum ML temperature anomaly, the upwelling should occur just before the autumn entrainment period. A warm water pool and a weakly stratified seasonal thermocline are then created, which will be entrained further. At the same time, there will be no or little transfer of nitrate and chlorophyll during the entrainment period.

\section{c. Regionalization of DCM impact}

To make a first guess of regions where the DCM indeed impacts the surface layer, it is assumed that the DCM is located at nitracline depth (defined as the depth where nitrate concentration is equal to $1 \mu \mathrm{M}$ ) as generally observed in the world oceans. Nitracline depth is given by the World Ocean Atlas (2001) monthly climatology. The zIRR20 (see 6.a) is computed for an oligotrophic ocean (surface chlorophyll of $0.05 \mu \mathrm{g} 1^{-1}$ ). Monthly climatological values of surface irradiance values are from the CORE (Coordinated Ocean Reference Experiments) (Large and Yeager, 2004) dataset. At first guess, DCM has an impact on the temperature structure in regions where the nitracline is located above zIRR20. It is obviously a very crude first guess as these regions present different dynamical and atmospheric forcing characteristics. However, one can argue that the dynamics is indirectly taken in account as nitracline depth is considered, which depends both of vertical and horizontal motion. However the oligotrophic ocean assumption overestimates zIRR20.

To relax the constant surface chlorophyll concentration constraint, we use satellite- 
derived surface chlorophyll from SeaWIFS to determine zIRR20. Using satellite product may lead to in situ chlorophyll overestimation as satellite chlorophyll is integrated from the ocean surface down to the first optical depth (Stramska and Stramski, 2005). More light is then absorbed in the ocean upper layers, which underestimates zIRR20. Satellite data, such as SeaWIFS data, are also biased in the tropical Atlantic Ocean due to Sahara dust (Moulin et al., 2001). That being considered, using satellite data yields the same regions as before, but with less frequency and intensity.

These regions are mainly regions presenting shallow thermoclines and thus relatively strong vertical dynamics. Subpolar regions may be impacted one or two months per year in summer but the most important effect is seen on thermal domes (Figs. 12a and 1).

We compare the vertical velocities and the ML seasonal cycle of the GD region with the three other dome regions, using ORCA05 climatology (Fig. 13). In the ORCA05 model framework, the GD region is defined as the region spanning $10-14^{\circ} \mathrm{N} ; 28-24^{\circ} \mathrm{W}$, the Angola Dome region (eg: Yamagata and Lizuka, 1995) spans $6-10^{\circ} \mathrm{S} ; 8-4^{\circ} \mathrm{W}$, the South Indian thermocline ridge (e.g., Masumoto and Meyers, 1998; Vialard et al., 2009) region spans $6-10^{\circ} \mathrm{S} ; 64-68^{\circ} \mathrm{E}$, and the Costa Rica dome (e.g., Fiedler, 2002) region spans $10-14^{\circ} \mathrm{N}$; $112-108^{\circ} \mathrm{W}$. The four regions are characterized by a seasonal upwelling/downwelling with maximum values of about $10 \mathrm{~m}$ month $^{-1}$. The ML depth also presents a clear seasonal variations and its depth varies from $40 \mathrm{~m} / 60 \mathrm{~m}$ in winter to $15 / 25 \mathrm{~m}$ in summer. Upwelling occurs when ML is at its shallowest position, except near the Angola dome, where it occurs a few months before. The global pattern is comparable in all cases; the results we obtained in this study can then be extrapolated to other tropical thermal dome regions.

\section{Vertical resolution issue}

A problem which may prevent us from estimating the exact effect of the DCM directly in coupled dynamical-biogeochemical 3-D models is the vertical resolution. Indeed, in most OGCMs (such as ORCA05 for instance), the vertical resolution is set to $10 \mathrm{~m}$ from the surface down to the thermocline, which may alter the representation of the DCM which vertical resolution is often less than $10 \mathrm{~m}$ (see Fig. 2 for the GD). Consequently the heating induced by the DCM may be underestimated, as it depends on the sharp irradiance gradient (see 2.d). To test this hypothesis, we again perform the CHLDEEP and CHLSURF experiments changing the vertical resolution while keeping all other parameters identical. Four vertical resolutions are compared: $10 \mathrm{~m}, 5 \mathrm{~m}, 2.5 \mathrm{~m}$ and $1 \mathrm{~m}$ (Fig. 14). The 10-m resolution version fails to represent the DCM from July to September, as chlorophyll is high at the surface. Temperature differences between CHLDEEP and CHLSURF are weak $\left(+0.2\right.$ to $\left.-0.6^{\circ} \mathrm{C}\right)$ at the thermocline level. The DCM gets better represented when resolution increases $(5 \mathrm{~m}, 2.5 \mathrm{~m})$ : the chlorophyll gradient strengthens and the ML chlorophyll concentration is weaker than for the $10 \mathrm{~m}$ case. As a consequence, the CHLDEEP - CHLSURF temperature difference increases to reach maximal (resp minimal) values of $+1.4^{\circ} \mathrm{C}$ (resp $-1.2^{\circ} \mathrm{C}$ ) in the $2.5 \mathrm{~m}$ resolution version. The $1 \mathrm{~m}$ resolution version presents even greater temperature differences; the DCM is present 

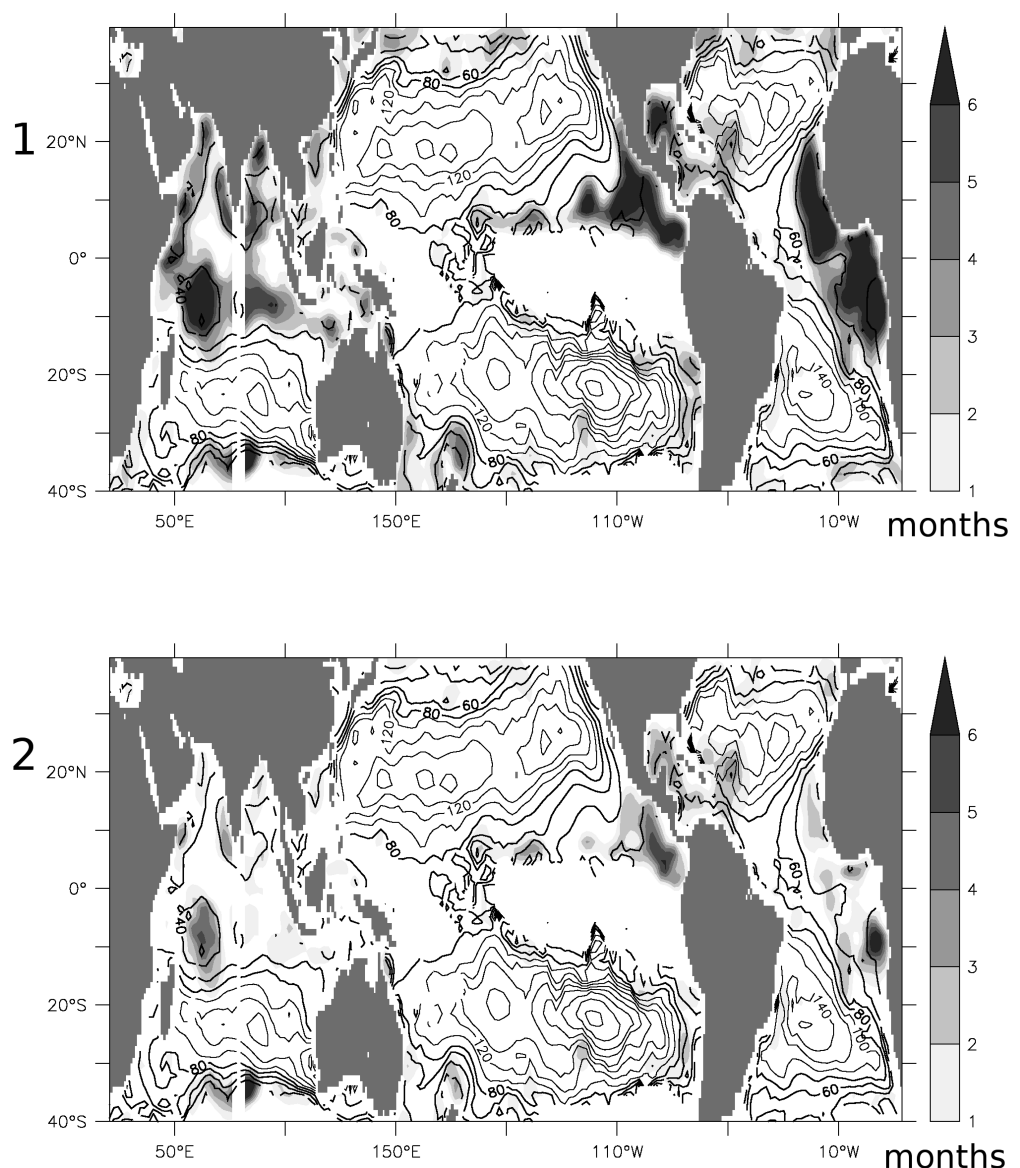

Figure 12. Number of months in a year when the DCM could have an effect on heat fluxes (nitracline depth shallower than the depth where irradiance is $20 \mathrm{Wm}^{-2}$ ). Nitracline has been computed from WOA2001. Surface irradiance is from CORE climatological data. Irradiance has been computed using the RGB model. Nitracline depth (m) (threshold $1 \mu \mathrm{M}$ ) is traced in contour. (1) constant surface chlorophyll (0.05 $\left.\mu \mathrm{g}^{-1}\right)$; (2) monthly climatological SeaWIFs chlorophyll.

throughout the year and the surface chlorophyll concentration is weak in better agreement with observations (Fig. 2). Finally, a test using $0.5 \mathrm{~m}$ resolution produced temperature patterns indistinguishable from the $1 \mathrm{~m}$ resolution patterns (not shown). Hence it can be concluded that using $1 \mathrm{~m}$ vertical resolution is the minimum requirement to adequately represent the impact of the DCM in the GD region. Moreover, for the specifics of the DCM impact, there does not seem to be a need for further increase of vertical resolution.

\section{Conclusion}

We have shown that the deep chlorophyll maximum can influence the upper ocean thermal structure and biogeochemistry using a 1-D coupled dynamical-biogeochemical model with $1 \mathrm{~m}$ 

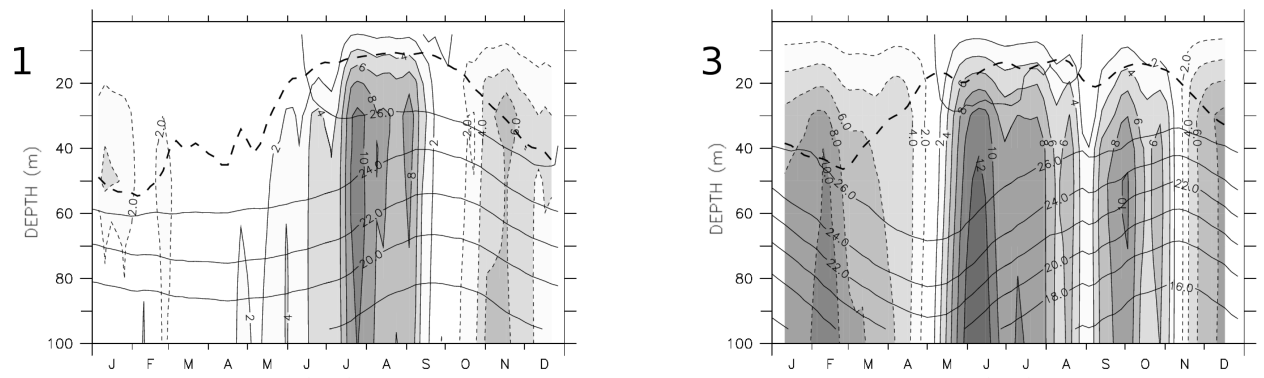

w (m/month)

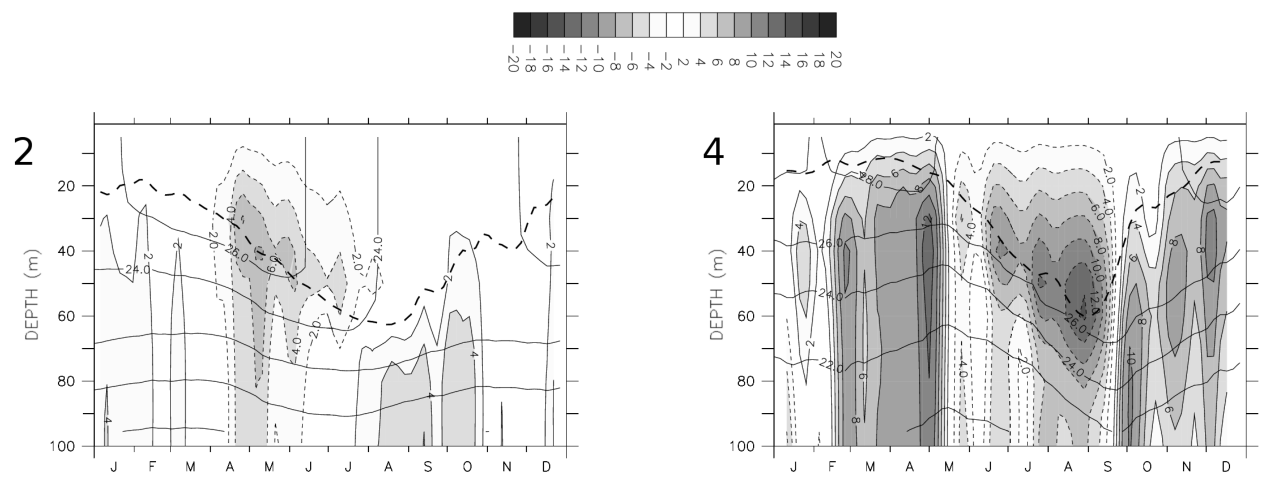

Figure 13. Climatological ORCA 05 vertical velocities $\left(\mathrm{m} \mathrm{month}^{-1}\right)$ (gray) and isotherms $\left({ }^{\circ} \mathrm{C}\right.$ ) (contour) at four locations. ML has been traced in dashes. Isotherms have been traced every 2 degrees. (1) Guinea Dome (mean $10^{\circ} \mathrm{N}-14^{\circ} \mathrm{N} ; 28^{\circ} \mathrm{W}-24^{\circ} \mathrm{W}$ ); (2) Angola Dome (mean $6^{\circ} \mathrm{S}-10^{\circ} \mathrm{S}$; $8^{\circ} \mathrm{W}-4^{\circ} \mathrm{W}$ ); (3) Seychelles Chagos Thermocline Ridge (mean $6^{\circ} \mathrm{S}-10^{\circ} \mathrm{S} ; 64^{\circ} \mathrm{E}-68^{\circ} \mathrm{E}$ ); (4) Costa Rica Dome (mean $\left.10-14^{\circ} \mathrm{N} ; 112^{\circ} \mathrm{W}-108^{\circ} \mathrm{W}\right)$.

vertical resolution. The Guinea Dome was chosen to test this effect among other candidate zones as its DCM presents a relatively high chlorophyll concentration $\left(1.1 \mu \mathrm{g} \mathrm{l}^{-1}\right)$ at a shallow depth ( $\sim 25 \mathrm{~m}$ ). Under these conditions, the DCM is directly responsible for a solar heat capture in the surface layers which increases the temperature by $+1{ }^{\circ} \mathrm{C}$ month ${ }^{-1}$ at the level where the chlorophyll gradient is greatest. Consequently, heating due to solar penetration decreases by $-0.1^{\circ} \mathrm{C}$ month $^{-1}$ below. Heat captured at the top of the DCM is advected upward during the doming season, leading to a weakening of the seasonal thermocline stratification. As a result, the permanent upper thermocline deepens and strengthens by $0.2^{\circ} \mathrm{C} \mathrm{m}^{-1}$ in better agreement with observation. Hence taking in account the effect of DCM in solar heat absorption improves the realism of modeled thermal stratification. This is an important result as OGCM thermocline is generally too diffuse (e.g., Vialard et al., 2001; Murtugudde et al., 2002; Lengaigne et al., 2006).

The mixed layer is also affected by the presence of the DCM. Its base deepens by $5 \mathrm{~m}$ and its temperature increases from 0.1 to $0.3^{\circ} \mathrm{C}$ from October to January, mainly due to increase of vertical diffusion and entrainment of warmer seasonal thermocline water from below. These 

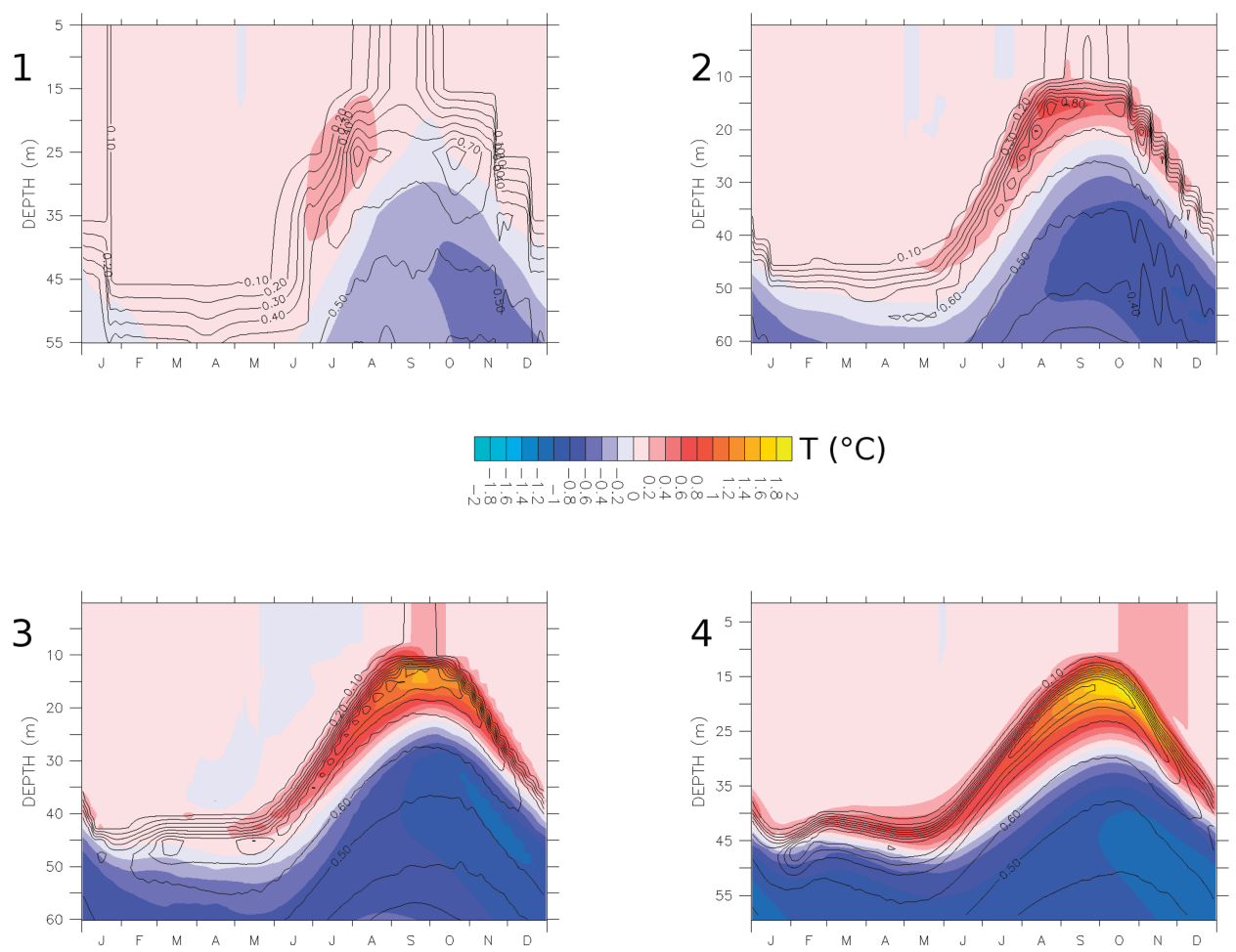

Figure 14. CHLDEEP - CHLSURF experiment temperature anomaly $\left({ }^{\circ} \mathrm{C}\right.$ ) (color) and CHLDEEP chlorophyll concentration $\left(\mu \mathrm{g}^{-1}\right.$ ) (contour) obtained with different vertical resolutions: (1) $10 \mathrm{~m}$ resolution; (2) $5 \mathrm{~m}$ resolution; (3) $2.5 \mathrm{~m}$ resolution; (4) $1 \mathrm{~m}$ resolution.

results are comparable to those proposed by Lewis et al. (1983) to a certain extent: using in situ data, they predicted a local heating in shallow DCM regions, leading to an increase of the ML depth associated with a vertical heat diffusion increase in the upper ocean. In our model, the DCM presence also generated temperature inversions that merit further investigations. Indeed, these temperature inversions compensated in density could warm the ML by entrainment or diffusion.

This entrainment/diffusion process also occurs with tracers: when DCM is taken in account in heat flux computation, nitrate concentration increase in the ML by $2.10^{-3} \mu \mathrm{M}$ in autumn, leading to an increase of surface chlorophyll concentration by nearly $50 \%\left(0.02 \mu \mathrm{g}^{-1}\right)$. Consequently, ML integrated primary production increases by 9 to $13 \mathrm{gC} \mathrm{m}^{-2} \mathrm{yr}^{-1}$ in winter. Below the ML, variations of nitrate, chlorophyll and PP are small but thermocline integrated is still smaller by a few percent, probably due to a ML deepening and thus an irradiance decrease at the DCM level.

As in all 1-D studies, the question of the influence of the 3-D environment must be raised, especially here as we wish to extend our results to other regions. The DCM is an ubiquitous 
feature of the world oceans and it is likely that the same mechanisms as those found in the Guinea Dome apply in other regions. To extrapolate our findings to other regions, we artificially increased the ML chlorophyll concentration in the model to reduce irradiance at DCM level, and then the DCM impact on solar penetrating heat. This DCM has a significant impact on heat fluxes when it receives at least $20 \mathrm{Wm}^{-2}$. We also tested the impact of a key factor, which is the seasonal cycle of the vertical advection. To transfer heat with the maximal efficiency in the ML upwelling should occur in summer, just before the entrainment period.

We identified in literature a wide range of regions which present a DCM shallow enough to have a potential impact on heat and nutrients fluxes. This test has been made comparing depth of irradiance $\left(20 \mathrm{~W} \mathrm{~m}^{-2}\right)$ to nitracline depth. These regions are located year-round in the tropic and in summer in subpolar regions, as long as a shallow DCM is associated with a sufficiently strong surface irradiance. Regions located near the thermal domes (GD, Angola dome, Seychelles Chagos Thermocline Ridge and Costa Rica dome) are particularly impacted. They present a comparable vertical velocity seasonal pattern, showing an upwelling in summer and a downwelling in winter by about $10 \mathrm{~m} \mathrm{month}^{-1}$. The results of this study may be generalized to these regions.

The retroaction of the DCM onto the nutrient fluxes in the surface layers may have a particular biogeochemical importance as the input of nutrients in the ML, which is supporting new production in spring, is not fully understood (Ledwell et al., 1993; Williams and Follows, 1998; Williams et al., 2006). Are these nutrients supplied mostly by horizontal advection? Or is entrainment involved? This question is particularly true in subtropical gyres. DCM could increase horizontal advection in these regions, as nitrate gradient between subtropical gyres and tropical regions should increase. Locally, DCM may also be responsible of a nutrient entrainment increase.

Experiences using a 3D OGCM should be made in order to describe how these processes interact at the globel scale. A problem of these 3D OGCM may nevertheless be the coarse vertical resolution, which is commonly of the order of $10 \mathrm{~m}$ in the upper layer. Indeed, the thickness of the DCM has the same size order. We have shown that using a higher vertical resolution $(1 \mathrm{~m})$ to test the potential impact of the DCM is mandatory. Improving vertical resolution in OGCMs is then an important step to take biological effects better in account.

Acknowledgments. This work was partially supported by grants from CAPES and CNPq, educational and research grants, respectively. This work was also partially supported by CNES through Ocean Surface Topgraphy-Science Team (OST-ST) Program.

\section{REFERENCES}

Agusti, S. and C. M. Duarte. 1999. Phytoplankton chlorophyll $a$ distribution and water column stability in the central atlantic ocean. Oce. Acta, 22, 193-203.

Aumont, O. and L. Bopp. 2006. Globalizing results from ocean in situ iron fertilization studies. Global Biogeochem. Cycles, 20, GB2017, doi:10.1029/2005GB002591.

Aumont, O., E. Maier-Reimer, S. Blain and P. Monfray. 2003. An ecosystem model of the global ocean including Fe, Si, P colimitations. Global Biogeochem. Cycles, 17, 1060, doi:10.1029/ 2001GB001745. 
Ballestero, D. 1999. Remote sensing of vertically structured phytoplankton pigments. Top. Meteor. Ocean., 6, 14-23.

Bopp, L., P. Monfray, O. Aumont, J.-L. Dufresne, H. LeTruet, G. Madec, L. Terray and J. Orr. 2001. Potential impact of climate change on marine export production. Global Biogeochem. Cycles, 15, 81-99.

Breves, G., W., R. Reuter, N. Delling and W. Michaelis. 2003. Fluorophores in the Arabian Sea and their relationship to hydrographic conditions. Ocean Dyn., 53, 73-85, doi:10.1007/s10236-0030025-z.

Chavez, F. P., S. K. Service and S. E. Buttrey. 1996. Temperature-nitrate relationships in the central and eastern tropical Pacific. J. Geophys. Res., 101(C9), 20,553-20,563.

Choi, J. K., J. H. Noh, K. S. Shin and K. H. Hong. 1995. The early autumn distribution of chlorophyll- $a$ and primary productivity in the Yellow Sea. The Yellow Sea, 1 68-80.

Collins, W. D., C. M., Bitz, M. L. Blackmon, G. B. Bonan, C. S. Bretherton, J. A. Carton, P. Chang, S. C. Doney, J. J. Hack, T. B. Henderson, J. T. Kiehl, W. G. Large, D. S. Mckenna, B. D. Santer and R. D. Smith. 2006. The community climate system model version 3 (ccsm3). J. Climate, 19 2122-2143.

Conkright, M. E., H. E. Garcia, T. D. O’Brien, R. A. Locarnini, T. P. Boyer, C. Stephens and J. Antonov. 2002. World Ocean Atlas 2001: Nutrients, Vol. 4, S. Levitus, ed., NOAA Atlas NESDIS 52, U.S. Government Printing Office, Wash., D.C., 392 pp., CD-ROMs.

Corredor, J. E., J. M. Morell, J. M. Lopez, and J. E. Capella. 2004. Cyclonic eddy entrains Orinoco River plume in Eastern Caribbean. EOS, 85, 197-197.

Cullen, J. J. and R. W. Eppley. 1981. Chlorophyll maximum layers of the Southern California Bight and possible mechanisms of their formation and maintenance. Oce. Acta, 4, 22-32.

Dandonneau, Y. 1979. Concentration en chlorophylle dans le pacique tropical sud ouest; comparison avec d'autres aires oceaniques tropicales. Oce. Acta., 2, 133-142.

De Boyer Montegut, C., G. Madec, A. Fischer, A. Lazar and D. Iudicone. 2004. Mixed layer depth over the global ocean: an examination of profile data and a profile-based climatology. J. Geophys. Res., 109, C12003, doi:10.1029/2004JC002378.

De Boyer Montegut, C., J. Mignot, A. Lazar and S. Cravatte. 2007. Control of salinity on the mixed layer depth in the world ocean. part i: general description. J. Geophys. Res., 112, C06011, doi:10.1029/2006JC003953.

Denman, K. L. 1973. A time-dependent model of the upper ocean. J. Phys. Oceanogr., 3, 173-184.

Ditullio, G. R., M. E. Geesey, D. R. Jones, K. L. Daly, L. Campbell and Smith. 2003. Phytoplankton assemblage structure and primary productivity along $170^{\circ} \mathrm{W}$ in the South Pacific Ocean. Mar. Eco. Prog. Ser., 255, 55-80.

Faugeras, B., M. Levy, L. Memery, J. Verron, J. Blum and I. Charpentier. 2003. Can biogeochemical fluxes be recovered from nitrate and chlorophyll data? A case study assimilating data in the northwestern Mediterranean Area at the JGOFS-dyfamed station. J. Mar. Sys., 40, 99-125.

Fiedler, P. 2002. The annual cycle and biological effects of the Costa Rica dome. Deep-Sea Res. I, 49, 321-338, doi:doi:10.1016/S0967-0637(01)00057-7.

Foltz, G. R., S. A. Grodsky, J. A. Carton and M. J. McPhaden. 2003. Seasonal mixed layer heat budget of the tropical Atlantic Ocean. J. Geophys. Res., 108, C5, 3146+, doi:10.1029/ 2002JC001584.

Gaspar, P., Y. Gregoris and J.-M. Lefevre. 1990. A simple eddy kinetic energy model for simulations of the oceanic vertical mixing: Tests at Station Papa and long-term upper ocean study site. J. Geophys. Res. 95, C9, 16179-16193.

Herbland, A. and B. Voituriez. 1979. Hydrological structure analysis for estimating the primary production in the tropical Atlantic Ocean. J. Mar. Res., 37, 87-101.

Jerlov, N. G. 1976. Marine Optics, Elsevier, 231 pp. 
Large, W. and G. Yeager. 2004. Diurnal to decadal global forcing for ocean and sea-ice models: data sets and fluxes climatologies. Technical Report TN-460+STR, NCAR, 105.

Lazaro, C., J. M. Fernandes-Santos and P. Oliveira. 2005. Seasonal and interannual variability of surface circulation in the Cape Verde region from 8 years of merged t/p and ers- 2 altimeter data. Rem. Sens. Env., 98, 45-62.

Ledwell, J. R., A. J. Watson and C. S. Law. 1993. Evidence for slow mixing across the pycnocline from an open-ocean tracer-release experiment. Nature, 364, 701-703.

Lengaigne, M., C. Menkes, O. Aumont, T. Gorgues, L. Bopp, J.-M. Andre and G. Madec. 2006. Influence of the oceanic biology on the tropical pacific climate in a coupled general circulation model. Clim. Dyn., 28, 503-516, doi:10.1007/s00382-006-0200-2.

Lewis, M. R., M.-E. Carr, G. C. Feldman, W. Esaias and C. McClain. 1990. Influence of penetrating solar radiation on the heat budget of the equatorial Pacific Ocean. Nature, 347, 6293, 543-545, doi: $\underline{10.1038 / 347543 \mathrm{a} 0 .}$.

Lewis, M. R., J. J. Cullen and T. Platt. 1983. Phytoplankton and thermal structure in the ocean: Consequences of nonuniformity in chlorophyll profile. J. Geophys. Res., 88, 2565-2570.

Madec, G., P. Delecluse, M. Imbard and C. Levy. 1999. OPA 8.1 ocean general circulation model reference manual. Technical report, Laboratoire d'Oceanographie Dynamique et de Climatologie, Paris, France.

Manizza, M., C. Le Quere, A. J. Watson and E. T. Buitenhuis. 2005. Bio-optical feedbacks among phytoplankton, upper ocean physics and sea-ice in a global model. Geophys. Res. Lett., 32, L05603+, doi: 10.1029/2004GL020778.

Marzeion, B., A. Timmermann, R. Murtugudde and F. F. Jin. 2005. Biophysical feedbacks in the tropical Pacific. J. Climate, 18, 58-70.

Masumoto, Y. and G. Meyers. 1998. Forced Rossby waves in the southern tropical Indian Ocean. J. Geophys. Res., 103, 27589-27602.

Menkes, C. E., S. Kennan, P. Flament, Y. Dandonneau, S. Masson, B. Biessy, E. Marchal, G. El-din, J. Grelet, Y. Montel, A. Morliere, A. Lebourges-Dhaussy, C. Moulin, G. Chahampalbert and A. Herbland. 2002. A whirling ecosystem in the equatorial Atlantic. Geophys. Res. Lett., 29, 11, 1553, doi: 10.1029/2001GL014576.

Menkes, C. E. R., J. G. Vialard, S. C. Kennan, J. P. Boulanger, and G. V. Madec. 2006. A modeling study of the impact of tropical instability waves on the heat budget of the eastern equatorial Pacific, J. Phys. Oceanogr. 36, 847-865.

Mignot, J., C. de Boyer Montegut, A. Lazar and S. Cravatte. 2007. Control of salinity on the mixed layer depth in the world ocean. Part II: Tropical areas. J. Geophys. Res., 112, C10010, doi: 10.1029/2006JC003954.

Monfray, P., O. Aumont, J.-L. Dufresne, H. Le Treut, G. Madec, L. Terray and J. C. Orr. 2001. Potential impact of climate change on marine export production. Global Biogeochem. Cycles, 15, 81-100, doi:10.1029/1999GB001256.

Morel, A. 1988. Optical modeling of the upper ocean in relation to its biogenous matter content (case 1 waters). J. Geophys. Res., 93, C9, 10749-10768.

Morel, A. and D. Antoine. 1994. Heating rate within the upper ocean in relation to its bio-optical state. J. Phys. Oceanogr., 24, 1652-1665.

Moulin, C., H. R. Gordon, R. M. Chomko, V. F. Banzon and R. H. Evans. 2001. Atmospheric correction of ocean color imagery through thick layers of Saharan dust. Geophys. Res. Lett., 28, 1, 5-8.

Murtugudde, R., J. Beauchamp, C. R. McClain, M. Lewis and A. J. Busalacchi. 2002. Effects of penetrative radiation on the upper tropical ocean circulation. J. Climate, 15, 470-486.

Nakamoto, S., P. S. Kumar, J. M. Oberhuber, J. Ishizaka, K. Muneyama and R. Frouin. 2001. Response of the equatorial Pacific to chlorophyll pigment in a mixed layer isopycnal ocean general circulation model. Geophys. Res. Lett., 28, 2021-2024. 
Oschlies, A. 2004. Feedbacks of biotically induced radiative heating on upper-ocean heat budget, circulation, and biological production in a coupled ecosystem-circulation model. J. Geophys. Res., 109, C12031+, doi:10.1029/2004JC002430.

Oschlies, A. and V. Garcon. 1999. An eddy resolving coupled physical-biological model of the North Atlantic. Part I: sensitivity to advection numerics and mixed layer physics. Global Biogeochem. Cycles, 13, 135-160.

Paulson, C. A. and J. J. Simpson. 1977. Irradiance measurements in the upper ocean. J. Phys. Oceanogr., 7, 952-956.

Richardson, A. J., M. C. Pfa, J. G. Field, N. F. Silulwane and F. A. Shillington. 2002. Identifying characteristic chlorophyll $a$ problems in the coastal domain using an artificial neural network. J. Plankton Res., 24, 1289-1303, doi:10.1093/plankt/24.12.1289.

Robins, D. and J. Aiken. 1996. The Atlantic meridional transect: an oceanographic research programme to investigate physical, chemical, biological and optical variables of the Atlantic Ocean. Underwater tech., 21, 8-14.

Sathyendranath, S., A. D. Gouveia, S. R. Shetye, P. Ravindran, and T. Platt. 1991. Biological control of surface temperature in the Arabian Sea. Nature, 349, 6304, 54-56, doi:10.1038/349054a0.

Sharples, J., M. C. Moore, T. P. Rippeth, P. M. Holligan, D. J. Hydes, N. R. Fisher and J. H. Simpson. 2001. Phytoplankton distribution and survival in the thermocline. Limnol. Oceanogr., 46, 486-496.

Siedler, G. N. Zangenberg, R. Onken and A. Morliere. 1992. Seasonal changes in the tropical Atlantic circulation: Observation and simulation of the Guinea Dome. J. Geophys. Res., 97, 703-715.

Stramska, M. and D. Stramski. 2005. Effects of a nonuniform vertical profile of chlorophyll concentration on remote-sensing reflectance of the ocean. App. Optics, 44, 1735-1747.

Vaillancourt, R. D., J. Marra, M. P. Seki, M. L. Parsons and R. R. Bidigare. 2003. Impact of a cyclonic eddy on phytoplankton community structure and photosynthetic competency in the subtropical North Pacific Ocean. Deep-Sea Res. I. 50, 829-847.

Vialard, J., C. Menkes, J. P. Boulanger, P. Delecluse, E. Guilyardi, M. J. McPhaden, and G. Madec. 2001. A model study of oceanic mechanisms affecting equatorial Pacific sea surface temperature during the 1997-98 El Nino. J. Phys. Oceanogr., 31, 1649-1675.

Vialard, J., J. P. Duvel, M. McPhaden, E. Key, B. Ward, P. Bourouet-Aubertot, D. Bourras, R. Weller, P. Minnnet, A. Weill, C. Cassou, L. Eymard, T. Fristed, C. Basdevant, Y. Dandonneau, O. Duteil, T. Izumo, C. Montegut-De Boyer, and S. Masson. 2009. The CIRENE cruise: air sea interactions in the Seychelles-Chagos Ridge region. Bull. Am. Met. Soc., 90, 45-61.

Voituriez, B. 1981. Les sous-courants equatoriaux nord et sud et la formation des domes thermiques tropicaux. Oce. Acta, 4, 497-506.

Voituriez, B. and Y. Dandonneau. 1974. Relation entre la structure thermique, la production primaire et la regeneration des sels nutriptifs dans le dome de Guinee. Ser. Oce., 12, 4, 241-255.

Voiturrriez, B. and A. Herbland. 1983. Signication de la relation nitrate/temperature dans l'upwelling equatorial du Golfe de Guinee. Oce. Acta, 7, 2, 169-174.

Wetzel, P., M. E. Reimer, M. Botzet, J. Jungclaus, N. Keenlyside and M. Latif. 2007. Effects of ocean biology on the penetrative radiation in a coupled climate model. J. Climate, 19, 3973-3987.

Williams, R. G. and M. J. Follows. 1998. The Ekman transfer of nutrients and maintenance of new production over the North Atlantic. Deep-Sea Res. I, 45, 461-489.

Williams, R. G., V. Roussenov and M. J. Follows. 2006. Nutrient streams and their induction into the mixed layer. Glob. Biogeochem. Cycles., 20, 1016, doi:10.1029/2005GB002586.

Yamagata, T. and S. Iizuka. 1995. Simulation of the tropical thermal domes in the Atlantic: A seasonal cycle. J. Phys. Oceanogr., 25, 2129-2140. 